\title{
Manipulating Nitrogen and Water Resources for Improved Cool Climate Vine to Wine Quality
}

\author{
Harriet V. Walker, ${ }^{1 *}$ Joanna E. Jones, ${ }^{1}$ Nigel D. Swarts, ${ }^{1}$ and Fiona Kerslake ${ }^{1}$
}

\begin{abstract}
Low yeast assimilable nitrogen (YAN) concentrations $(<140 \mathrm{mg} / \mathrm{N} / \mathrm{L})$ can produce wines with inferior aroma and flavor, regardless of supplemental nitrogen $(\mathrm{N})$ additions in the winery. The impact of doubling commercial field $\mathrm{N}$ and irrigation rates was explored in Vitis vinifera L. cv. Chardonnay and Pinot noir over three growing seasons (2016 to 2019) in Southern Tasmania, Australia, to improve YAN concentrations and observe the concurrent influence on vine canopy, yield, and grape and wine composition. Six combinations of irrigation and $\mathrm{N}$ rates were applied to 20 vines for each treatment combination and replicated across both cultivars. The treatments included the standard irrigation rate ( $530 \mathrm{~L} /$ vine/year $)$ / control N (0 kg/N/ha/year) rate, standard irrigation / standard commercial $\mathrm{N}$ rate $(\sim 18 \mathrm{~kg} / \mathrm{N} / \mathrm{ha} /$ year $)$, standard irrigation / double commercial $\mathrm{N}$ rate $(\sim 36 \mathrm{~kg} / \mathrm{N} / \mathrm{ha} /$ year), double irrigation rate ( $\sim 1060 \mathrm{~L} /$ vine/year) / control N, double irrigation / standard $\mathrm{N}$, and double irrigation / double N. Analysis of variance was used to determine main treatment effects and treatment interactions of the measured variables for a subset of the vine population in each growing season. Increasing $\mathrm{N}$ rate improved YAN concentrations in both cultivars in two of three growing seasons, with the double $\mathrm{N}$ rate associated with increasing YAN to acceptable ( $>140 \mathrm{mg} / \mathrm{N} / \mathrm{L})$ levels. Irrigation had no impact on YAN concentrations. Treatment influences on vine vegetative growth, yield, and grape and wine composition were marginal, inconsistent, and largely influenced by climatic conditions. Cool-climate grapegrowers would benefit from applying more $\mathrm{N}$ in the vineyard around veraison to improve YAN without stimulating vigor or reducing the quality of grape and wine chemical composition. Increasing irrigation rates may be advantageous in seasons with high crop load; however, current commercial irrigation rates are considered adequate.
\end{abstract}

Key words: irrigation, nitrogen fertilization, vineyard management, wine composition, yeast assimilable nitrogen (YAN), yield

In vineyards, nitrogen $(\mathrm{N})$ is required to achieve sustainable yields in a manner that maintains overall vine balance and produces grapes that meet winery specifications. In cool climate regions, $\mathrm{N}$ fertilization is recommended at modest rates $(20 \mathrm{~kg} / \mathrm{N} / \mathrm{ha}$ ) (AWRI 2010) to avoid excess vine vigor (Spayd et al. 1993, Neilsen et al. 2010), which can disrupt source-sink relationships (Vasconcelos et al. 2009), alter canopy microclimate (Bell and Henschke 2005), increase disease pressure (Thomidis et al. 2016), and negatively affect berry

${ }^{1}$ Tasmanian Institute of Agriculture, University of Tasmania, Hobart, TAS, Australia.

*Corresponding author (harriet.walker@utas.edu.au)

Acknowledgments: This research was supported by Wine Australia. The authors thank the staff of the Jansz Parish vineyard of Hill-Smith Family Vineyards for the experimental site and samples obtained. The authors also thank David Hayward \& Thomas Koo from the Tasmanian Institute of Agriculture, Reiko Horiuchi (University of Tasmania exchange student), and Paul Smart from Wine Tasmania for technical assistance.

Supplemental data is freely available with the online version of this article at www.ajevonline.org.

Manuscript submitted Jan 2021, revised March 2021, Aug 2021, Sept 2021, accepted Sept 2021

This is an open access article distributed under the CC BY license (https:// creativecommons.org/licenses/by/4.0/).

By downloading and/or receiving this article, you agree to the Disclaimer of Warranties and Liability. The full statement of the Disclaimers is available at http://www.ajevonline.org/content/proprietary-rights-notice-ajev-online. If you do not agree to the Disclaimers, do not download and/or accept this article. doi: 10.5344/ajev.2021.21004 composition (Kliewer 1977, Hilbert et al. 2003). Achieving $\mathrm{N}$ balance is important, as inadequate $\mathrm{N}$ can result in low yields, poor fruit ripening, and reduced yeast assimilable nitrogen (YAN) (Bell and Henschke 2005), while excess N can result in adverse environmental impacts, such as waterway contamination via leaching (Nováková and Nágel 2009) and the release of potent greenhouse gases (Swarts et al. 2016).

YAN is comprised of ammonium ions and free alphaamino acids, which serve as key nutrient sources for yeast and dictate the speed and efficiency of fermentation (Hannam et al. 2013). Suboptimal YAN concentrations can lead to stuck or sluggish fermentations, production of undesirable metabolites such as hydrogen sulfide (Jiranek et al. 1995), and other wine faults (Bell and Henschke 2005). The YAN threshold to ferment grape juice to dryness under moderate initial sugar concentrations is $140 \mathrm{mg} / \mathrm{N} / \mathrm{L}$ (Bell and Henschke 2005, Hannam et al. 2013); however, the interplay of other fermentation impacts, such as yeast strain, can influence YAN requirements (Bell and Henschke 2005). As growers limit $\mathrm{N}$ applications to manage vine vigor and fruit quality, low YAN concentrations remain a key issue in cool-climate winemaking regions such as Tasmania.

In the winery, low juice and must YAN concentrations are often supplemented by adding ammonium salts such as diammonium phosphate (DAP). This can prevent problems associated with fermentation kinetics, yet only increases ammonium and thereby creates an unbalanced must (Bell and Henschke 2005). As amino acid composition is an integral 
part of wine flavor and aroma, it is preferred to optimize grape $\mathrm{N}$ concentration in the vineyard (Holzapfel et al. 2015).

Several studies have demonstrated that $\mathrm{N}$ application in the vineyard increases berry amino $\mathrm{N}$ and YAN (Bell et al. 1979, Hilbert et al. 2003, Linsenmeier et al. 2008, Hannam et al. 2013), yet the impact on vine vegetative variables and on grape and wine composition is less clear. In a long-term, 15year trial, Riesling pruning weights, leaf size, yield, and must amino acids were reduced in a zero-N control compared to $\mathrm{N}$-fertilized treatments $(30,60$, and $90 \mathrm{~kg} / \mathrm{N} / \mathrm{ha}$ ) (Linsenmeier et al. 2008). Reduced grape must titratable acidity (TA) and increased must $\mathrm{pH}$ was reported in the $90 \mathrm{~kg} / \mathrm{N} / \mathrm{ha}$ treatment, yet there were no other notable impacts of $\mathrm{N}$ rate on grape quality. Similarly, in a 5-year trial in British Columbia, Merlot juice $\mathrm{pH}$ increased with increasing $\mathrm{N}$ rate $(0,16.6,32.2$, and $64.4 \mathrm{~kg} / \mathrm{N} / \mathrm{ha}$ ) in three of the trial years, yet juice total soluble solids (TSS; Brix), juice TA, and yield were largely unaffected (Hannam et al. 2013). Grape juice YAN concentration increased with $\mathrm{N}$ rate, but only the highest $\mathrm{N}$ application rate $(64.4 \mathrm{~kg} / \mathrm{N} / \mathrm{ha})$ consistently increased YAN over the trial period, and in two out of the five trial years, YAN concentrations did not reach the desired $140 \mathrm{mg} / \mathrm{N} / \mathrm{L}$ minimum threshold. In another British Columbian trial, there was no impact of $\mathrm{N}$ rates (40 and $80 \mathrm{~kg} / \mathrm{N} / \mathrm{ha}$ ) on Merlot yield (per vine) and no consistent impact of $\mathrm{N}$ rate on yield components, juice $\mathrm{pH}$, or juice TA, while juice TSS tended to be lower at the higher $\mathrm{N}$ rate (Neilsen et al. 2010). There were adequate $(>140$ $\mathrm{mg} / \mathrm{N} / \mathrm{L}$ ) YAN concentrations in the $80 \mathrm{~kg} / \mathrm{N} / \mathrm{ha}$ treatment, while standard commercial rates $(40 \mathrm{~kg} / \mathrm{N} / \mathrm{ha})$ frequently resulted in low YAN concentrations $(<140 \mathrm{mg} / \mathrm{N} / \mathrm{L})$ (Neilsen et al. 2010). In Washington State, there was increased juice and wine $\mathrm{pH}$ in Riesling with increasing $\mathrm{N}$ rates $(0,56,112$, and $224 \mathrm{~kg} / \mathrm{N} / \mathrm{ha}$ ), but no impact on juice and wine TA was reported (Spayd et al. 1994). Juice total amino $\mathrm{N}$, including free amino $\mathrm{N}$, increased linearly with $\mathrm{N}$ rate, but reduced wine total phenolics was also observed and attributed to dense canopy development.

The high variability of the impact of $\mathrm{N}$ fertilization, the limited research conducted in cool climate wine regions, and the lack of studies exploring the impact of $\mathrm{N}$ on YAN in tandem with vine vegetative growth, yield, and grape and wine composition has led to uncertainty within the industry, resulting in modest $\mathrm{N}$ applications and low YAN concentrations that require winery $\mathrm{N}$ additions to prevent fermentation issues. A benchmark $\mathrm{N}$ application rate in the vineyard that improves YAN concentrations without negatively impacting vine vigor and grape and wine composition is yet to be determined.

As nutrient uptake by grapevines depends on water flow through the soil-root-shoot pathway (Keller 2005), water availability and $\mathrm{N}$ fertilization impact grapevine physiology and grape and wine composition collectively. The impact of irrigation level under low $\mathrm{N}$ supply on vine vigor, yield, and grape and wine composition has not been determined and the effect of water availability on YAN has been varied (Wade et al. 2004, Keller 2005, Hannam et al. 2013, Holzapfel et al. 2015).

The current study was undertaken to investigate the impact of doubling annual $\mathrm{N}(\sim 18 \mathrm{~kg} / \mathrm{N} / \mathrm{ha})$ and irrigation $(\sim 530$
L/vine) rates on vine vigor, vegetative growth, yield, and grape and wine composition of Vitis vinifera Chardonnay and Pinot noir vines in a cool-climate vineyard. We tested the hypothesis that increased $\mathrm{N}$ application rates under additional irrigation will increase YAN concentration in the grape juice must. We also investigated the influence of additional $\mathrm{N}$ and irrigation inputs on vegetative growth, yield, and grape and wine composition and explored the influence of climatic conditions on these variables over three growing seasons.

\section{Materials and Methods}

Trial site and experimental design. The trial was established in winter 2016, at a commercially managed vineyard (Coal River Valley, Southern Tasmania, 4245'S; $147^{\circ} 29^{\prime} \mathrm{E}$ ) in Australia using $V$. vinifera L. cv. Pinot noir (clone 115) and Chardonnay (clone 95) three-year-old vines on Paulsen 1103 rootstock. Vines were vertically shoot-positioned and bilaterally cane-pruned to 16 nodes per vine, plus two 2-node spurs. Vine spacing was $1.25 \mathrm{~m}$ with a row spacing of $2.5 \mathrm{~m}$. The Chardonnay block was planted with a south-east row orientation on a shallow black soil on dolerite, comprised of a black clay loam, A1 horizon to $50 \mathrm{~mm}$ deep, on top of a heavy black clay A1-2 horizon (50 to $300 \mathrm{~mm}$ ), with underlying B1 and B2 soil horizons characterized as brown heavy clays (200 to $1200 \mathrm{~mm}$ ). The Pinot noir block was planted with a north-west row orientation on a lateritic sandy loam with a grey sandy loam A1 horizon to $100 \mathrm{~mm}$ deep, with clay content gradually increasing down the soil profile to a sandy clay loam B1 horizon (100 to $200 \mathrm{~mm}$ ) and sandy clay B2 horizon (200 to $700 \mathrm{~mm}$ ) on top of a mudstone $\mathrm{C}$ horizon.

Prior to setting up the experiment, the vineyard was scouted for appropriate cultivar blocks with relatively flat landscapes and uniform soil type within the treatment rows. N and irrigation treatments were integrated into the commercial vineyard irrigation infrastructure and controlled by the grower to simulate true commercial conditions over the three-vintage period. As such, treatments were established in two rows, one reflecting the standard growers practice irrigation regime (SI) and the other, the double standard irrigation rate (DI). This was achieved by adding an extra irrigation drip line (Netafim) in the DI row flowing at the same rate $(\mathrm{L} / \mathrm{hr})$ as the original line. All the drip lines had pre-existing holes set $0.3 \mathrm{~m}$ apart and the second drip line was off-set, resulting in only a 0.15 $\mathrm{m}$ gap between holes. Within each row, vines received no $\mathrm{N}$ for the control rate $(0 \mathrm{~N})$, the "standard" grower's annual $\mathrm{N}$ practice rate (ST) or "double" the grower's standard N practice (DBL) rate (Table 1). The three $\mathrm{N}$ treatments were applied to 20 neighboring vines down the length of each row in treatment blocks to allow ease of management for the grower to accurately maintain the treatment protocol. Within each treatment, eight monitor vines of similar vigor and health were tagged for measurement and sample collection. The treatments were controlled through a series of taps, maintained at the start of each row, to supply either fertigation or irrigation at the desired times. This resulted in six treatment combinations: SI/0N, SI/ST, SI/DBL, DI/0N, DI/ST, and DI/DBL. 
The standard $\mathrm{N}$ treatment was determined by the grower and considered dry ash analysis ( $\mathrm{N}$ removal from fruit from previous harvest), the previous season's yield, historic site data, vine number/ha, soil analysis, and petiole nitrate. The double $\mathrm{N}$ treatment delivered double the annual standard $\mathrm{N}$ rate for each site through a second, newly-installed fertigation drip line.
$\mathrm{N}$ fertilizer (type, timing, and delivery) varied across blocks and vintages at the discretion of the vineyard manager to reflect standard commercial vineyard practice (Tables 2 and 3). Application of other macro- and micronutrients were managed by the grower and were uniform across the treatment blocks and rows. These were chosen in accordance with fertilizer budgets and additional nutrient requirements (e.g.,

Table 1 Nitrogen (control, standard, or double) and irrigation (standard or double) treatment rates for Chardonnay and Pinot noir cultivars for the 2016/17, 2017/18, and 2018/19 production seasons (May to April).

\begin{tabular}{|c|c|c|c|c|c|c|c|}
\hline & & \multicolumn{3}{|c|}{ Chardonnay } & \multicolumn{3}{|c|}{ Pinot noir } \\
\hline & & $2016 / 17$ & $2017 / 18$ & $2018 / 19$ & $2016 / 17$ & $2017 / 18$ & $2018 / 19$ \\
\hline \multirow[t]{3}{*}{ Nitrogen (kg/N/ha) } & Control & 0 & 0 & 0 & 0 & 0 & 0 \\
\hline & Standard & 15.6 & 18.1 & 21.2 & 16.1 & 15.0 & 21.2 \\
\hline & Double & 31.2 & 36.2 & 42.2 & 32.3 & 30.0 & 42.2 \\
\hline \multirow[t]{2}{*}{ Irrigation (L/vine) } & Standard & 432.4 & 578.6 & 561.2 & 443.5 & 598.6 & 568.1 \\
\hline & Double & 864.8 & 1157.2 & 1122.4 & 887.0 & 1197.2 & 1136.2 \\
\hline
\end{tabular}

Table 2 Nitrogen (N) fertilizer source, rate, and timing of application across the trial period (2016 to 2019) for Chardonnay.

\begin{tabular}{|c|c|c|c|c|c|c|}
\hline \multirow[b]{2}{*}{ Fertilizer } & \multicolumn{2}{|c|}{$2016 / 17$} & \multicolumn{2}{|c|}{$2017 / 18$} & \multicolumn{2}{|c|}{ 2018/19 } \\
\hline & $\begin{array}{l}\text { Application } \\
\text { date }\end{array}$ & $\begin{array}{c}\text { Rate } \\
(\mathrm{kg} / \mathrm{N} / \mathrm{ha})\end{array}$ & $\begin{array}{l}\text { Application } \\
\text { date }\end{array}$ & $\begin{array}{c}\begin{array}{c}\text { Rate } \\
(\mathrm{kg} / \mathrm{N} / \mathrm{ha})\end{array} \\
\end{array}$ & $\begin{array}{l}\text { Application } \\
\text { date }\end{array}$ & $\begin{array}{c}\begin{array}{c}\text { Rate } \\
\text { (kg/N/ha) }\end{array} \\
\end{array}$ \\
\hline $\begin{array}{l}\text { Liquid N (32.3\%) plus humic acid } \\
\text { (Nitro Humus } 323)\end{array}$ & 17 Feb & 4.29 & - & - & - & - \\
\hline $\begin{array}{l}\text { N (42\%) a plus fulvic and seaweed extract } \\
\text { (VitalGold } 42)\end{array}$ & 17 March & 8.35 & 18 Jan & 6.30 & - & - \\
\hline $\begin{array}{l}\text { Calcium nitrate }(13.1 \% \mathrm{~N} \text {, Campbells } \\
\text { Aqua-Fert) }\end{array}$ & $17 \mathrm{Feb}$ & 1.12 & $18 \mathrm{Feb}$ & 2.62 & - & - \\
\hline $\begin{array}{l}\text { Calcium nitrate plus boron (15.5\% N, } \\
\text { Aqua-Fert Calcium Nitrate + Boron) }\end{array}$ & - & - & $18 \mathrm{Feb}$ & 3.10 & - & - \\
\hline \multirow[t]{2}{*}{ Ammonium (15.8\% N, Campbells Nitro-P) } & $17 \mathrm{Feb}$ & 1.41 & $18 \mathrm{Feb}$ & 2.37 & $19 \mathrm{Feb}$ & 4.66 \\
\hline & - & - & 18 March & 3.16 & $19 \mathrm{Feb}$ & 4.66 \\
\hline $\begin{array}{l}\text { Fish emulsion }(2.5 \% \mathrm{~N} \text {, Sustainable Farming } \\
\text { Solutions) }\end{array}$ & 17 May & 0.42 & 18 April & 0.50 & - & - \\
\hline \multirow[t]{2}{*}{$\mathrm{N}(42.5 \% \text {, Easy } \mathrm{N})^{\mathrm{b}}$} & - & - & - & - & 19 Jan & 8.49 \\
\hline & - & - & - & - & 19 Jan & 6.37 \\
\hline Total N/season & & 15.6 & & 18.1 & & 21.2 \\
\hline
\end{tabular}

a Nitrogen as ammonium (10.5\%), nitrate $(10.5 \%)$, and urea $(21 \%)$.

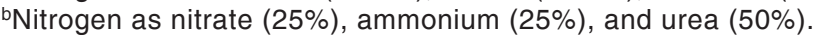

Table 3 Nitrogen (N) fertilizer source, rate, and timing of application across trial period (2016 to 2019) for Pinot noir.

\begin{tabular}{|c|c|c|c|c|c|c|}
\hline \multirow[b]{2}{*}{ Fertilizer } & \multicolumn{2}{|c|}{$2016 / 17$} & \multicolumn{2}{|c|}{$2017 / 18$} & \multicolumn{2}{|c|}{$2018 / 19$} \\
\hline & $\begin{array}{l}\text { Application } \\
\text { date }\end{array}$ & $\begin{array}{c}\text { Rate } \\
\text { (kg/N/ha) }\end{array}$ & $\begin{array}{l}\text { Application } \\
\text { date }\end{array}$ & $\begin{array}{c}\text { Rate } \\
\text { (kg/N/ha) }\end{array}$ & $\begin{array}{l}\text { Application } \\
\text { date }\end{array}$ & $\begin{array}{c}\text { Rate } \\
\text { (kg/N/ha) }\end{array}$ \\
\hline $\begin{array}{l}\text { Liquid N (32.3\%) plus humic acid (Nitro } \\
\text { Humus } 323 \text { ) }\end{array}$ & 17 Feb & 5.98 & - & - & - & - \\
\hline $\begin{array}{l}\mathrm{N}(42 \%)^{\mathrm{a}} \text { plus fulvic and seaweed extract } \\
\text { (VitalGold } 42)\end{array}$ & 17 March & 8.03 & 18 Jan & 6.30 & - & - \\
\hline $\begin{array}{l}\text { Calcium Nitrate ( } 13.1 \% \text { N, Campbells Aqua- } \\
\text { Fert) }\end{array}$ & $17 \mathrm{Feb}$ & 1.18 & $18 \mathrm{Feb}$ & 2.62 & - & - \\
\hline \multirow[t]{2}{*}{ Ammonium (15.8\% N, Campbells Nitro-P) } & 17 Feb & 0.49 & $18 \mathrm{Feb}$ & 2.37 & $19 \mathrm{Feb}$ & 4.66 \\
\hline & - & - & 18 March & 3.16 & 19 Feb & 4.66 \\
\hline $\begin{array}{l}\text { Fish emulsion ( } 2.5 \% \mathrm{~N} \text {, Sustainable Farming } \\
\text { Solutions) }\end{array}$ & 17 May & 0.48 & 18 April & 0.50 & - & - \\
\hline \multirow[t]{2}{*}{$\mathrm{N}(42.5 \%, \text { Easy } \mathrm{N})^{\mathrm{b}}$} & - & - & - & - & 19 Jan & 8.49 \\
\hline & - & - & - & - & 19 Jan & 6.37 \\
\hline Total N/season & & 16.6 & & 15.0 & & 21.2 \\
\hline
\end{tabular}

aNitrogen as ammonium (10.5\%), nitrate (10.5\%), and urea $(21 \%)$.

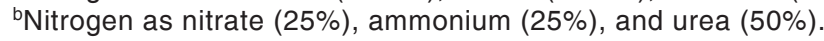


calcium, boron, phosphorous). In 2016/17, N fertilizer was first applied in mid-February, while it was applied in midJanuary in 2017/18, and in late January in 2018/19 for both cultivars.

Irrigation scheduling and duration of application were controlled by the vineyard manager, subject to cultivar requirements and seasonal conditions (Table 1). Irrigation volume (iNTELLiTROL, MAIT industries) and soil moisture (AquaCheck, MAIT industries) were monitored at each site for each growing season and the timing of application was monitored in the Pinot noir block via the installation of flow meters (GSD8, BMeters) in both the standard and double irrigation lines to ensure treatments were managed as desired. Irrigation was generally applied at a lower limit of 50\% readily available water and terminated when soil moisture reached field capacity. Evapotranspiration was also monitored by the vineyard manager throughout the season to track water requirements and help determine irrigation frequency via an onsite weather station (Vaisala weather transmitter WXT520).

Vines were shoot-thinned in spring at Eichhorn-Lorenz stage (E-L) 15 and trimmed in summer to $40 \mathrm{~cm}$ above top canopy wire height ( $\approx 130 \mathrm{~cm}$ shoot length). Additionally, the Chardonnay vines were leaf-plucked after bloom. Leaf plucking was targeted at the fruiting zone just above the cordon to remove enough leaves to expose fruit to dappled light. Both blocks were netted just prior to veraison (E-L 35). The trial was held over three consecutive growing seasons (2016/17, 2017/18, and 2018/19).

Climatic conditions. Tasmania has a cool, temperate climate, with an annual 30 -year mean rainfall of $\approx 600 \mathrm{~mm}$ as described on the Australian Bureau of Meteorology website (www.bom.gov.au). Southern Tasmania has mild summer temperatures (average $16.8^{\circ} \mathrm{C}$ ), relatively cool winter temperatures (average $8.8^{\circ} \mathrm{C}$ ), and an overall maritime influence. The winegrape growing season extends from September (budbreak) to April/May (leaf fall). Weather data was obtained from the on-site weather station (Vaisala weather transmitter WXT520) located $\sim 500 \mathrm{~m}$ from each trial site and historic climate data was sourced from the closest Bureau of Meteorology site (Hobart Airport, Tasmania) located $\approx 10 \mathrm{~km}$ away from the field site. Annual growing season weather data was recorded from May to April. For each production season, climatic conditions were split into four phases, dictated by important phenological stages, for further analysis: dormancy to budbreak (1 May to $31 \mathrm{Aug}$ ), budbreak to bloom (1 Sept to $31 \mathrm{Nov}$ ), bloom to veraison (1 Dec to $31 \mathrm{Jan}$ ), and veraison to harvest (1 Feb to 30 April) (Supplemental Table 1).

Field measurements and lab analysis. Canopy analysis. Vine canopy size was determined each growing season in January on three randomly selected monitor vines per treatment using the modified point quadrat method for estimating canopy structure of grapevines (Poni et al. 1996). A long, firm, and thin $(\sim 1 \mathrm{~m} \times 2 \mathrm{~mm})$ length of wire was inserted into the canopy fruiting zone at pre-determined randomly generated heights between 80 and $115 \mathrm{~cm}$. Contact with leaves, clusters, and gaps was recorded to determine gaps (\%), leaf layer number (LLN), and the number of leaves and fruit clus- ters per vine. Any contact with the cordon, stems, petioles, and peduncles was ignored as per the modifications of the original method presented by Poni et al. (1996). To ensure an unbiased random sample, measurements were repeated 40 times per vine at randomly generated points marked on a drop sheet of $1.25 \mathrm{~m}$ in length to represent the projected canopy length.

Vine vigor. Vines were bi-laterally cane-pruned by hand each season, according to the previous practice at the site. Prunings, excluding the old wood ( $>1$-year-old), were weighed in four vines per treatment using a set of digital hanging scales (model WS603, Wedderburn). The same vine was measured each year to determine the cumulative impact of treatments on vine vigor.

Leaf nitrogen analysis. Leaves were sampled for $\mathrm{N}$ analysis at harvest in the 2017/18 and 2018/19 growing seasons. Thirty leaves were collected at random and pooled across five neighboring vines to make one sample. This was repeated another three times in each treatment block $(n=4)$. The leaves within each sample were dried at $60^{\circ} \mathrm{C}$, hand-crushed, and mixed to obtain a homogenous sample. Samples were ground to a fine powder using a Mixer Mill MM 200 (Retsch), and total $\mathrm{N}$ analysis was performed using a Thermo Finigan EA 1112 Series Flash Elemental Analyzer (Thermo Fisher Scientific, Inc.). Total $\mathrm{N}$ analysis occurred as described (Walker et al. 2021).

Yield analysis. Grapes were hand-harvested at target commercial ripeness of 21 Brix. Before picking, the total number of clusters on each tagged monitor vine was counted $(n=8)$. Five random clusters were subsampled per monitor vine, and a sample was considered as the sum of the two neighboring monitor vines $(n=4)$. The clusters were kept cool and frozen later that day for analysis. For four of the 10 clusters, cluster weight (g), cluster density (OIV scale [OIV 2009]), and number of berries per cluster were recorded. Berry size was evaluated by sieving the berries into small $(<2 \mathrm{~mm})$, medium ( 2 to $10 \mathrm{~mm})$, and large $(>10 \mathrm{~mm})$ size categories. The number of small berries was generally very low; therefore, the small and medium berry size categories were combined as $<10 \mathrm{~mm}$.

Microvinification. Small-scale winemaking, or microvinification, was undertaken on the day of harvest or on the following day, after clusters were refrigerated at $4{ }^{\circ} \mathrm{C}$ overnight and then warmed to ambient temperature prior to processing. For red winemaking, $\approx 1 \mathrm{~kg}$ harvested fruit per sample (one sample $=$ grape collection from five neighboring vines) was weighed as whole clusters before being destemmed and crushed by hand. The remaining clusters were frozen for future grape homogenate analysis of YAN and grape composition (phenolics, tannins, and anthocyanins). The must generated from the $1 \mathrm{~kg}$ fruit was decanted into 1.5 L BodumTM 'Kenya' coffee vessels and $\approx 100 \mathrm{~mL}$ juice was sampled and frozen for chemical analysis, including TSS, pH, and TA (g/L). Fifty mg/L potassium metabisulfite (PMS) was added to each Bodum. After a minimum of $10 \mathrm{~min}, \mathrm{RC} 212$ (Lallemand) yeast was rehydrated and added at $0.4 \mathrm{~g} / \mathrm{L}$. Grapes were fermented on skins for seven days at $27^{\circ} \mathrm{C}\left( \pm 1^{\circ} \mathrm{C}\right)$ using a modified version of the "Bodum French Press" method (Dambergs and Sparrow 2011) 
as described (Carew et al. 2014). The ferments were monitored and weighed daily, with daily weight loss indicating ongoing fermentation through the release of carbon dioxide (Carew et al. 2014). On day 3, $200 \mathrm{mg} / \mathrm{L}$ DAP was added to each ferment as a yeast nutrient source to ensure progression and completion of fermentation, in reflection of standard winery practice when YAN is considered low $(<140 \mathrm{mg} / \mathrm{N} / \mathrm{L})$. The end of fermentation was confirmed using Clinitest reagent tablets for sugar testing (Bayer) via the five-drop method and considered complete when sugar was $<0.25 \mathrm{~g} / \mathrm{L}$. The wines were decanted into $375 \mathrm{~mL}$ green glass sparkling bottles, covered with parafilm, and left at ambient temperature for $24 \mathrm{hrs}$ to ensure complete alcoholic fermentation. The bottles were crown-sealed and stored at $4{ }^{\circ} \mathrm{C}$ for two weeks to promote settling. The settled wine was racked under $\mathrm{CO}_{2}$ cover, stabilized by adding $60 \mathrm{mg} / \mathrm{L}$ PMS, then left for a further two weeks at ambient temperature before final racking under $\mathrm{CO}_{2}$ cover into three $50 \mathrm{~mL}$ amber glass bottles for each replicate. The wines were stored in a dark room at ambient temperature $(\sim 20$ to $23^{\circ} \mathrm{C}$ ) until analysis.

For white winemaking, $\approx 2 \mathrm{~kg}$ grape clusters from the four five-vine samples were basket-pressed (1.3 L, Ferrari) to extract $700 \mathrm{~mL}$ juice (35\% extraction). One hundred $\mathrm{mL}$ pressed juice was collected and frozen for chemical analysis (TSS, pH, TA, YAN, and total phenolics) and $\approx 600 \mathrm{~mL}$ filtered juice was transferred for microvinification into $500 \mathrm{~mL}$ Schott bottles, leaving no headspace and fit with an airlock. To break down pectin and prevent protein haze formation, 50 $\mathrm{mg} / \mathrm{L}$ PMS and $1 \mathrm{~mL} / \mathrm{L}$ VinoClear classic enzyme (Winequip) were added to each replicate. The juice was cold-settled at $4^{\circ} \mathrm{C}$ for seven days, after which the clear juice was racked and warmed to 12 to $14^{\circ} \mathrm{C}$ before adding $200 \mathrm{mg} / \mathrm{L}$ DAP and inoculating with EC1118 (Lallemand) yeast at $0.3 \mathrm{~g} / \mathrm{L}$. The juice was fermented at $14^{\circ} \mathrm{C}$ for two weeks and finished at $20^{\circ} \mathrm{C}$ for $\approx 1$ week. Wines were fermented to dryness $(<2.5 \mathrm{~g} / \mathrm{L})$ and settled at $4{ }^{\circ} \mathrm{C}$ for one week, then racked under $\mathrm{CO}_{2}$ cover and stabilized by adding $80 \mathrm{mg} / \mathrm{L}$ PMS. The wines were left for a further two weeks at ambient temperature $\left(\sim 20\right.$ to $\left.23^{\circ} \mathrm{C}\right)$ before further racking into three $50-\mathrm{mL}$ amber glass bottles, leaving no headroom, and stored at ambient temperature.

Juice analysis. Juice samples were defrosted overnight at $4^{\circ} \mathrm{C}$ and centrifuged (Hettich Universal 320R) at $4000 \mathrm{rpm}$ for $10 \mathrm{~min}$ to clarify. TSS was measured using a hand-held digital refractometer (Pocket Refractometer Pal-1) and $\mathrm{pH}$ and TA were measured using an auto-titrator (702 Metrohm SM Titrino, Metrohm). The consistency of each method was tested by duplicating measurements of every fourth (refractometer) and tenth (auto-titrator) sample. Total phenolics was measured in clarified Chardonnay juice samples using UV-vis spectrometry as described (Kerslake et al. 2018). Total phenolics were measured in absorbance units (AU) and calculated as the absorbance at $280 \mathrm{~nm}$ (Iland et al. 2004).

Grape analysis. The $100 \mathrm{~g}$ subsamples of frozen Pinot noir grapes from each sample were defrosted at $4^{\circ} \mathrm{C}$ overnight. An Ultra Turrax T25 (Ika) was used at 4186 relative centrifugal force (rcf) for two blocks of $30 \mathrm{sec}$. For YAN analysis, $50 \mathrm{~g}$ grapes was homogenized. The homogenate for YAN analysis used only raw material and did not include ethanol extraction. The samples were centrifuged at $1450 \mathrm{rcf}$ for $10 \mathrm{~min}$ to clarify before analysis.

The other $50 \mathrm{~g}$ grapes was used as an homogenate for anthocyanin extraction as described (Iland et al. 1996). UVvisible spectroscopy was used to measure total phenolics, anthocyanins, and tannins, which were calculated using the Australian Wine Research Institute WineCloud (AWRI).

$Y A N$. Chardonnay juice samples and Pinot noir homogenate samples (no ethanol extraction) were used to measure YAN using Vintessential Laboratories (Melbourne) Ammonia Nitrogen and Primary Amino Acid Nitrogen test kits according to the manufacturer's instructions.

Wine analysis. In each trial season, Chardonnay wine samples were clarified by centrifugation (Hettich Universal 320R), diluted 1:5 in $1 \mathrm{M} \mathrm{HCl}$, and dark-incubated at ambient temperature $\left(20\right.$ to $\left.22^{\circ} \mathrm{C}\right)$ for one hour, before scanning at 280 $\mathrm{nm}$ with a spectrophotometer (Genesys 10S, Thermo). Total phenolics was calculated using absorbance at $280 \mathrm{~nm}$ (Iland et al. 2004). Total phenolics, total anthocyanins, total tannins, total pigment and non-bleachable pigment were quantified using UV-visible spectroscopy for the Pinot noir wine samples in the 2017/18 and 2018/19 growing seasons using the modified Somers method (Mercurio et al. 2007).

Data analysis. All data were analyzed using IBM SPSS Statistics V22. The data were subjected to normality tests prior to analysis. Analysis of variance (ANOVA) was used to test for significant differences of the dependent variables due to the fixed effects of $\mathrm{N}$ and irrigation treatments, and the treatment interaction term. Each ANOVA model was limited to a single year. Tukey's post-hoc test was used to determine significant differences among sample means at $\alpha=0.05$.

\section{Results}

Weather. Mean daily temperatures for the trial period were below the historic average, yet the mean maximum and minimum temperatures were higher and there was more solar radiation. Each growing season was warmer and drier than the previous over the three-year trial period. The 2017/18 season had the most growing degree days (Table 4).

Canopy architecture and vine vigor. In Chardonnay, there were fewer cluster contacts with double irrigation in $2017 / 18$, but only in the standard N treatment (Table 5). No other treatment interactions were observed among the Chardonnay block within the measured canopy variables. There were no interactions between $\mathrm{N}$ and irrigation treatments on vine canopy (effective insertions [\%], gaps [\%], leaf contacts, or LLN) in the Pinot noir block over the three trial seasons.

$\mathrm{N}$ treatments did not affect leaf contacts and LLN in either Chardonnay or Pinot noir over the three trial seasons (Table 5). Effective insertions and gaps varied between 90.2 and 98.4\% and 1.6 and $9.8 \%$ for Chardonnay and between 89.9 and $98.7 \%$ and 1.3 and $10.2 \%$ for Pinot noir, respectively, but no $\mathrm{N}$ effects were detected.

The influence of irrigation rate on vine canopy was season-dependent (Table 5). Effective insertions (\%) and gaps (\%) were unaffected by irrigation rate across cultivars and 
seasons, ranging from 90.4 to $98.6 \%$ and 1.4 to $9.6 \%$ for Chardonnay and 89.9 to $97.7 \%$ and 2.3 to $10.1 \%$ for Pinot noir, respectively. Leaf contacts, LLN, and cluster contacts responded inconsistently to irrigation treatments (Table 5). In 2017/18, vine canopy was less dense in Pinot noir, but denser in Chardonnay, under the double irrigation treatment, as demonstrated by the number of leaf contacts and LLN. In Chardonnay in 2016/17 and Pinot noir in 2018/19, double irrigation increased cluster contacts over standard irrigation.

In Chardonnay, pruning weights were lower in the control (0N) treatment in 2018/19 (Table 5). In Pinot noir, pruning weights increased in the double $\mathrm{N}$ treatment in $2018 / 19$, but only in comparison to the standard $\mathrm{N}$ treatment. The double irrigation treatment increased pruning weights in both Pinot noir and Chardonnay in 2017/18 and in Pinot noir only in 2018/19 (Table 5). No other irrigation treatment effects were observed.
Leaf N. In 2017/18, both cultivars exhibited a decrease in leaf $\mathrm{N}(\%)$ as a result of the double irrigation treatment at harvest (Table 6). Similar results were observed for leaves collected at harvest in the 2018/19 growing season, but the means in Table 4 are representative of pooled leaves from each of the four treatment replicates, and statistical analysis could not be undertaken. In 2017/18, lower leaf N was observed in the control N Chardonnay treatment, yet no response was observed in Pinot noir (Table 6). In 2018/19, a trend for increased leaf $\mathrm{N}$ with increasing $\mathrm{N}$ rate was observed in both cultivars.

Yield analysis. The interaction between $\mathrm{N}$ and irrigation treatments on yield variables varied among seasons for both cultivars. For Chardonnay in 2016/17, both the number of berries per cluster and cluster density were greater under double irrigation, yet only in the double $\mathrm{N}$ treatment (Table 7). Cluster weight also increased with double irrigation under both

\begin{tabular}{lcrr}
\hline \multicolumn{2}{c}{ Table 4 Climate data from the on-site weather station in the 2016/17, 2017/18, and 2018/19 production seasons (May to April) } \\
with historic climate data (1991 to 2020) obtained from the Hobart Airport weather station. MJ, megajoules.
\end{tabular}

aGDD represents growing degree days, calculated using a base of $10^{\circ} \mathrm{C}$.

bThe online database for solar radiation was only available starting in 2009.

Table 5 Dormant pruning weights and vegetative growth variables, as measured by the modified point quadrat method, for Vitis vinifera Chardonnay and Pinot noir grapevines in response to nitrogen and irrigation treatments across the trial period (2016 to 2019). LLN, leaf layer number.

\begin{tabular}{|c|c|c|c|c|c|c|c|c|c|}
\hline & \multicolumn{3}{|c|}{ Leaf contacts } & \multicolumn{3}{|c|}{ LLN } & \multicolumn{3}{|c|}{ Pruning weights (kg) } \\
\hline & $2016 / 17$ & $2017 / 18$ & $2018 / 19$ & $2016 / 17$ & $2017 / 18$ & $2018 / 19$ & $2016 / 17$ & $2017 / 18$ & $2018 / 19$ \\
\hline \multicolumn{10}{|l|}{$\begin{array}{l}\text { Chardonnay } \\
\text { Nitrogen }\end{array}$} \\
\hline Control (ON) & 60.5 & 84.0 & 89.7 & 1.51 & 2.10 & 2.24 & 1.13 & 1.00 & $0.71 \mathrm{a}^{\mathrm{a}}$ \\
\hline Standard & 63.8 & 87.0 & 97.0 & 1.60 & 2.18 & 2.43 & 1.32 & 1.27 & $1.45 \mathrm{~b}$ \\
\hline Double & 54.5 & 83.0 & 97.3 & 1.36 & 2.08 & 2.43 & 1.25 & 1.39 & $1.52 \mathrm{~b}$ \\
\hline Significance & $n s^{b}$ & ns & ns & ns & ns & ns & ns & ns & $\star \star \star$ \\
\hline \multicolumn{10}{|l|}{ Irrigation } \\
\hline Standard & 55.4 & 77.1 & 95.7 & 1.39 & 1.93 & 2.39 & 1.14 & 1.00 & 1.34 \\
\hline Double & 63.8 & 92.2 & 93.7 & 1.59 & 2.31 & 2.34 & 1.33 & 1.44 & 1.17 \\
\hline Significance & ns & ** & ns & ns & * & ns & ns & ** & ns \\
\hline Interaction & ns & ns & ns & ns & ns & ns & ns & ns & ns \\
\hline \multicolumn{10}{|l|}{ Pinot noir } \\
\hline \multicolumn{10}{|l|}{ Nitrogen } \\
\hline Control (ON) & 52.2 & 57.7 & 90.8 & 1.3 & 1.4 & 2.3 & 0.93 & 0.92 & $1.06 \mathrm{ab}$ \\
\hline Standard & 50.0 & 63.0 & 88.0 & 1.3 & 1.6 & 2.2 & 0.75 & 0.86 & $0.94 \mathrm{a}$ \\
\hline Double & 48.5 & 63.0 & 95.0 & 1.2 & 1.6 & 2.4 & 0.84 & 1.22 & $1.57 b$ \\
\hline Significance & ns & ns & ns & ns & ns & ns & ns & ns & * \\
\hline \multicolumn{10}{|l|}{ Irrigation } \\
\hline Standard & 53.7 & 66.0 & 94.1 & 1.34 & 1.65 & 2.35 & 0.86 & 0.75 & 0.99 \\
\hline Double & 46.8 & 56.4 & 88.4 & 1.17 & 1.41 & 2.21 & 0.82 & 1.25 & 1.39 \\
\hline Significance & ns & * & ns & ns & * & ns & ns & $* *$ & ns \\
\hline Interaction & ns & ns & ns & ns & ns & ns & ns & ns & ns \\
\hline
\end{tabular}

aLowercase letters denote significant differences between treatment means as determined by Tukey's post-hoc test.

$\mathrm{b}^{*},{ }^{* *},{ }^{* * *}$ means significantly different at $p=0.05,0.01,0.001$, respectively, or not significantly (ns) different. 
control and double $\mathrm{N}$ rates (Table 7). Interactions between $\mathrm{N}$ and irrigation were also observed in Pinot noir in 2016/17 for cluster weights and the ratio of berry size $(>10 \mathrm{~mm}:<10$ $\mathrm{mm}$ ) (Table 8). In 2016/17, the number of big berries $(>10$ $\mathrm{mm}$ ) in Pinot noir was lower with double irrigation in the control $\mathrm{N}$ treatment, but increased by double irrigation in the double $\mathrm{N}$ treatment. In the same season, the number of small

\begin{tabular}{|c|c|c|c|c|}
\hline & \multicolumn{2}{|c|}{ Chardonnay } & \multicolumn{2}{|c|}{ Pinot noir } \\
\hline & $2017 / 18$ & $2018 / 19^{a}$ & $2017 / 18$ & $2018 / 19$ \\
\hline \multicolumn{5}{|l|}{ Nitrogen } \\
\hline Control & $1.42 \mathrm{a}^{\mathrm{b}}$ & 1.53 & 1.54 & 1.92 \\
\hline Standard & $1.65 \mathrm{~b}$ & 1.71 & 1.50 & 2.06 \\
\hline Double & $1.77 \mathrm{~b}$ & 1.85 & 1.68 & 2.30 \\
\hline Significance & $\star \star \star c$ & & ns & \\
\hline \multicolumn{5}{|l|}{ Irrigation } \\
\hline Standard & 1.66 & 1.74 & 1.68 & 2.20 \\
\hline Double & 1.56 & 1.65 & 1.47 & 1.83 \\
\hline Significance & * & & $* *$ & \\
\hline
\end{tabular}

aln 2018/19, samples were pooled, so no statistical analysis could be performed.

'Lowercase letters denote significant differences between treatment means as determined by Tukey's post-hoc test.

${ }^{c *},{ }^{* *},{ }^{* * *}$ means significantly different at $p=0.05,0.01,0.001$, respectively, or not significantly (ns) different. to medium-sized $(<10 \mathrm{~mm})$ berries increased with double irrigation, but only in the standard $\mathrm{N}$ treatment (Table 8 ).

For Chardonnay in 2017/18, the number of small- to medium-sized berries $(<10 \mathrm{~mm})$ was lower with double irrigation at both standard $\mathrm{N}$ and double $\mathrm{N}$ rates, but no treatment effect was observed in the control $\mathrm{N}$ treatment (Table 7). For Pinot noir in 2017/18, double irrigation reduced the number of small to medium sized berries $(<10 \mathrm{~mm})$, but only in the control $\mathrm{N}$ treatment (Table 8).

Main effects of the $\mathrm{N}$ treatments on yield variables were also inconsistent across cultivars and seasons. In Chardonnay in 2018/19, yield was lower in the control $\mathrm{N}$ treatment than in the double $\mathrm{N}$ treatment (Table 9). This was driven by a decrease in cluster number, larger berries $(>10 \mathrm{~mm})$, the ratio of berry size $(>10 \mathrm{~mm}:<10 \mathrm{~mm})$, and cluster weight in the control $\mathrm{N}$ treatment (Tables 9 and 10). In Pinot noir in $2016 / 17$, the double $\mathrm{N}$ treatment had a greater average cluster count than the standard $\mathrm{N}$ treatment, while there were fewer berries per cluster in the standard $\mathrm{N}$ treatment than the double $\mathrm{N}$ treatment (Table 11). No differences between double $\mathrm{N}$ or standard $\mathrm{N}$ with control $\mathrm{N}$ were observed in the above variables. $\mathrm{N}$ treatments had no significant impact on berry size or berry size ratio in Pinot noir (data not shown).

Irrigation treatments influenced cluster weight, berry number, and berry size, although treatment effects were inconsistent across cultivars and seasons. In Chardonnay, the average cluster count decreased with the double irrigation rate

Table 7 Interactive effects of nitrogen and irrigation treatments on yield characteristics and fruit and wine composition of Chardonnay in three growing seasons (2016 to 2019).

\begin{tabular}{|c|c|c|c|c|c|c|c|c|c|c|c|}
\hline \multirow[b]{2}{*}{ Irrigation } & \multirow[b]{2}{*}{ Nitrogen } & \multicolumn{4}{|c|}{$2016 / 17$} & \multicolumn{3}{|c|}{$2017 / 18$} & \multicolumn{3}{|c|}{$2018 / 19$} \\
\hline & & $\begin{array}{c}\text { Berries per } \\
\text { cluster }\end{array}$ & $\begin{array}{l}\text { Cluster } \\
\text { weight }\end{array}$ & $\begin{array}{l}\text { Cluster } \\
\text { density }\end{array}$ & $\begin{array}{c}\text { Juice } \\
\text { phenolics } \\
\text { (AU) }\end{array}$ & $\begin{array}{l}\text { Cluster } \\
\text { density }\end{array}$ & $\begin{array}{l}\text { Berries } \\
\text { per cluster } \\
<10 \mathrm{~mm}\end{array}$ & $\begin{array}{c}\text { Wine } \\
\text { phenolics } \\
\text { (AU) }\end{array}$ & $\begin{array}{l}\text { Berries } \\
\text { per cluster } \\
<10 \mathrm{~mm}\end{array}$ & Wine $\mathrm{pH}$ & $\begin{array}{c}\text { Wine } \\
\text { phenolics } \\
\text { (AU) }\end{array}$ \\
\hline \multirow[t]{3}{*}{ Standard } & Control & 157.4 & 112.7 & 4.1 & 2.01 & 6.8 & 10.0 & 1.01 & 33.8 & 3.09 & 1.11 \\
\hline & Standard & 168.1 & 136.3 & 5.6 & 1 & 8.6 & 22.7 & 0.99 & 35.3 & 3.09 & 1.11 \\
\hline & Double & 123.4 & 107.9 & 4.4 & 1.06 & 7.0 & 11.4 & 1.03 & 23.9 & 3.14 & 1.1 \\
\hline \multirow[t]{3}{*}{ Double } & Control & 167.1 & 155.5 & 6.5 & 1.23 & 6.9 & 10.9 & 0.91 & 101.6 & 3.14 & 1.12 \\
\hline & Standard & 138.0 & 148.3 & 6.1 & 0.98 & 8.0 & 8.8 & 1.03 & 43.1 & 3.12 & 1.03 \\
\hline & Double & 163.7 & 184 & 6.0 & 1.01 & 8. & 6.1 & 1.03 & 27.1 & 3.09 & 1.09 \\
\hline Interaction & & *a & ** & * & * & * & $* *$ & * & $* *$ & * & * \\
\hline
\end{tabular}

${ }^{a *}$ and ${ }^{* *}$ means significantly different at $p=0.05$ and 0.01 , respectively.

Table 8 Interactive effects of nitrogen and irrigation treatments on yield characteristics and fruit and wine composition of Pinot noir in three growing seasons (2016 to 2019).

\begin{tabular}{|c|c|c|c|c|c|c|c|c|}
\hline \multirow[b]{2}{*}{ Irrigation } & \multirow[b]{2}{*}{ Nitrogen } & \multicolumn{4}{|c|}{$2016 / 17$} & \multirow{2}{*}{$\begin{array}{c}2017 / 18 \\
\text { Berries } \\
\text { per cluster } \\
<10 \mathrm{~mm}\end{array}$} & \multicolumn{2}{|c|}{$2018 / 19$} \\
\hline & & $\begin{array}{c}\text { Cluster } \\
\text { weight (g) }\end{array}$ & $\begin{array}{c}\text { Berries } \\
\text { per cluster } \\
>10 \mathrm{~mm}\end{array}$ & $\begin{array}{c}\text { Berries } \\
\text { per cluster } \\
<10 \mathrm{~mm}\end{array}$ & $\begin{array}{c}\text { Berry size } \\
\text { ratio } \\
(>10:<10 \mathrm{~mm})\end{array}$ & & $\begin{array}{c}\text { Wine } \\
\text { phenolics } \\
\text { (AU) }\end{array}$ & $\begin{array}{c}\text { Wine tannins } \\
(\mathrm{g} / \mathrm{L})\end{array}$ \\
\hline \multirow[t]{3}{*}{ Standard } & Control & 115.6 & 81.3 & 87.8 & 1.2 & 68.1 & 28.1 & 0.3 \\
\hline & Standard & 93.3 & 45.5 & 54.6 & 0.9 & 77.1 & 37.1 & 0.7 \\
\hline & Double & 118.1 & 53.6 & 62.8 & 0.9 & 64.1 & 22.6 & 0.2 \\
\hline \multirow[t]{3}{*}{ Double } & Control & 103.2 & 43.2 & 81.2 & 0.6 & 45.4 & 30.4 & 0.5 \\
\hline & Standard & 105.8 & 44.8 & 83.0 & 0.7 & 60.4 & 28.5 & 0.4 \\
\hline & Double & 149.4 & 82.6 & 46.6 & 1.8 & 57.9 & 23.7 & 0.3 \\
\hline Interaction & & *a & $\star * *$ & * & $* \star *$ & * & * & $* *$ \\
\hline
\end{tabular}

${ }^{a *},{ }^{* *},{ }^{* \star *}$ means significantly different at $p=0.05,0.01,0.001$, respectively. 
in 2016/17, but this effect was not observed in the following seasons (Table 9). In 2017/18, cluster weight increased in the double irrigation treatment, while in 2018/19, it decreased with double irrigation (Table 9). The decreased cluster weight in 2018/19 was coupled with a decrease in the number of big berries $(>10 \mathrm{~mm})$ (Table 10). In Pinot noir, the mean $(\mu)$ berry size ratio was higher with double irrigation in 2017/18 ( $\mu=$
3.2, $\mathrm{SE}=0.43)$ than with standard irrigation $(\mu=2.0, \mathrm{SE}=$ 0.24 ). In 2018/19, there were fewer berries per cluster (Table $9)$ and smaller berries $(<10 \mathrm{~mm})$ at the double irrigation rate $(\mu=64.6, \mathrm{SE}=6.87)$ compared to the standard irrigation treatment $(\mu=88.8, \mathrm{SE}=7.87)$.

Grape and wine composition. $Y A N$. Irrigation treatment had no impact on YAN in either cultivar over the three trial

Table 9 Yield characteristics of Chardonnay in response to nitrogen and irrigation rates in three growing seasons (2016 to 2019).

\begin{tabular}{|c|c|c|c|c|c|c|c|c|c|c|c|}
\hline & \multicolumn{3}{|c|}{$\begin{array}{c}\text { Yield } \\
\text { (kg/vine) }\end{array}$} & \multicolumn{3}{|c|}{ Cluster count } & \multicolumn{2}{|c|}{$\begin{array}{l}\text { Berries } \\
\text { per cluster }\end{array}$} & \multicolumn{2}{|c|}{$\begin{array}{c}\text { Cluster } \\
\text { weight (g) }\end{array}$} & \multirow{2}{*}{$\begin{array}{c}\begin{array}{c}\text { Cluster } \\
\text { density } \\
\text { (OIV) }\end{array} \\
2018 / 19 \\
\end{array}$} \\
\hline & $2016 / 17$ & $2017 / 18$ & $2018 / 19$ & $2016 / 17$ & $2017 / 18$ & 2018/19 & $2017 / 18$ & 2018/19 & $2017 / 18$ & $2018 / 19$ & \\
\hline \multicolumn{12}{|l|}{ Nitrogen } \\
\hline Control & 3.0 & 6.9 & $3.2 \mathrm{a}^{\mathrm{a}}$ & 23.1 & 31.6 & $22.3 \mathrm{a}$ & 141.4 & 126.6 & 217.5 & $141.7 \mathrm{a}$ & $4.3 \mathrm{a}$ \\
\hline Standard & 3.0 & 6.9 & $4.6 \mathrm{~b}$ & 21.5 & 30.3 & $24.8 \mathrm{~b}$ & 152.8 & 140.8 & 225.9 & $185.5 \mathrm{~b}$ & $4.6 \mathrm{a}$ \\
\hline Double & 3.5 & 6.5 & $5.3 \mathrm{~b}$ & 24.2 & 29.4 & $28.6 \mathrm{~b}$ & 134.7 & 133.8 & 211.6 & $187.2 \mathrm{~b}$ & $5.4 \mathrm{~b}$ \\
\hline Significance & $n s^{b}$ & ns & ** & ns & ns & * & ns & ns & ns & $\star * *$ & $* *$ \\
\hline \multicolumn{12}{|l|}{ Irrigation } \\
\hline Standard & 3.0 & 6.1 & 4.5 & 25.6 & 29.7 & 24.1 & 138.7 & 135.5 & 200.1 & 184.7 & 4.9 \\
\hline Double & 3.3 & 7.4 & 4.2 & 20.2 & 31.2 & 26.4 & 147.3 & 132.0 & 236.6 & 158.2 & 4.6 \\
\hline Significance & ns & ns & ns & $\star *$ & ns & ns & ns & ns & * & ** & ns \\
\hline
\end{tabular}

'Lowercase letters denote significant differences between treatment means as determined by Tukey's post-hoc test.

${ }^{b *},{ }^{* *},{ }^{* *}$ means significantly different at $p=0.05,0.01,0.001$, respectively, or not significantly (ns) different.

Table 10 Berry size of Chardonnay in response to nitrogen and irrigation rates in three growing seasons (2016 to 2019 ).

\begin{tabular}{|c|c|c|c|c|c|c|c|}
\hline & \multicolumn{3}{|c|}{ Berries >10 mm } & \multirow{2}{*}{$\begin{array}{c}\text { Berries } \\
<10 \mathrm{~mm} \\
2016 / 17\end{array}$} & \multicolumn{3}{|c|}{$\begin{array}{l}\text { Berry size ratio } \\
(>10:<10 \mathrm{~mm})\end{array}$} \\
\hline & $2016 / 17$ & $2017 / 18$ & $2018 / 19$ & & $2016 / 17$ & $2017 / 18$ & $2018 / 19$ \\
\hline \multicolumn{8}{|l|}{ Nitrogen } \\
\hline Control & 66.6 & 131.0 & $74.6 \mathrm{a}^{\mathrm{a}}$ & 119.6 & 0.9 & 20.9 & $2.4 \mathrm{a}$ \\
\hline Standard & 68.6 & 137.1 & $112.0 \mathrm{~b}$ & 79.9 & 1.6 & 17.9 & $3.4 \mathrm{a}$ \\
\hline Double & 74.8 & 125.9 & $114.6 \mathrm{~b}$ & 62.0 & 2.1 & 19.6 & $7.3 \mathrm{~b}$ \\
\hline Significance & $n s^{b}$ & ns & $\star \star *$ & ns & ns & ns & $* *$ \\
\hline \multicolumn{8}{|l|}{ Irrigation } \\
\hline Standard & 62.0 & 124.0 & 116.1 & 91.5 & 1.4 & 18.0 & 5.5 \\
\hline Double & 78.0 & 138.7 & 84.7 & 82.8 & 1.7 & 20.9 & 3.3 \\
\hline Significance & ns & ns & $\star \star \star *$ & ns & ns & ns & ns \\
\hline
\end{tabular}

aLowercase letters denote significant differences between treatment means as determined by Tukey's post-hoc test.

${ }^{b * *}$ and ${ }^{* * *}$ means significantly different at $p=0.01$ and 0.001 , respectively, or not significantly (ns) different.

Table 11 Yield characteristics of Pinot noir in response to nitrogen and irrigation rates in three growing seasons (2016 to 2019 ).

\begin{tabular}{|c|c|c|c|c|c|c|c|c|c|c|c|c|c|c|}
\hline & \multicolumn{3}{|c|}{$\begin{array}{c}\text { Yield } \\
\text { (kg/vine) }\end{array}$} & \multicolumn{3}{|c|}{ Cluster count } & \multicolumn{3}{|c|}{ Berries per cluster } & \multicolumn{2}{|c|}{$\begin{array}{c}\text { Cluster weight } \\
\text { (g) }\end{array}$} & \multicolumn{3}{|c|}{$\begin{array}{l}\text { Cluster density } \\
\text { (OIV) }\end{array}$} \\
\hline & $\begin{array}{c}2016 / \\
17\end{array}$ & $\begin{array}{c}2017 / \\
18\end{array}$ & $\begin{array}{c}2018 / \\
19\end{array}$ & $\begin{array}{c}2016 / \\
17\end{array}$ & $\begin{array}{c}2017 / \\
18\end{array}$ & $\begin{array}{c}2018 / \\
19\end{array}$ & $\begin{array}{c}2016 / \\
17\end{array}$ & $\begin{array}{c}2017 / \\
18\end{array}$ & $\begin{array}{c}2018 / \\
19\end{array}$ & $\begin{array}{c}2017 / \\
18\end{array}$ & $\begin{array}{c}2018 / \\
19\end{array}$ & $\begin{array}{c}2016 / \\
17\end{array}$ & $\begin{array}{c}2017 / \\
18\end{array}$ & $\begin{array}{c}2018 / \\
19\end{array}$ \\
\hline \multicolumn{15}{|l|}{ Nitrogen } \\
\hline Control & 3.5 & 6.0 & 4.1 & $30.7 a^{a}$ & 30.3 & 32.1 & $132.0 \mathrm{a}$ & 178.5 & 123.1 & 199.2 & 128.3 & 6.8 & 8.6 & 5.0 \\
\hline Standard & 2.9 & 6.2 & 3.5 & $27.8 \mathrm{a}$ & 31.4 & 32.8 & $109.0 \mathrm{~b}$ & 180.5 & 118.9 & 196.7 & 107.9 & 6.4 & 8.8 & 4.4 \\
\hline Double & 4.3 & 6.1 & 3.3 & $31.5 \mathrm{~b}$ & 31.4 & 28.8 & $130.4 \mathrm{a}$ & 168.3 & 114.9 & 191.5 & 112.3 & 7.1 & 8.8 & 4.3 \\
\hline Significance & $n s^{b}$ & ns & ns & * & ns & ns & * & ns & ns & ns & ns & ns & ns & ns \\
\hline \multicolumn{15}{|l|}{ Irrigation } \\
\hline Standard & 3.5 & 6.6 & 3.5 & 30.8 & 32.5 & 29.6 & 117.7 & 185.6 & 127.9 & 201.0 & 118.2 & 6.7 & 8.9 & 4.8 \\
\hline Double & 3.7 & 5.6 & 3.8 & 29.2 & 29.5 & 32.6 & 129.6 & 165.9 & 111.5 & 190.6 & 115.0 & 6.8 & 8.6 & 4.4 \\
\hline Significance & ns & ns & ns & ns & ns & ns & ns & ns & * & ns & ns & ns & ns & ns \\
\hline
\end{tabular}

'Lowercase letters denote significant differences between treatment means as determined by Tukey's post-hoc test.

b* means significantly different at $p=0.05$, or not significantly (ns) different. 
seasons (Tables 12 and 13). However, $\mathrm{N}$ treatment did influence YAN in both Pinot noir and Chardonnay. In Pinot noir, YAN was greatest with double $\mathrm{N}$ in 2017/18. In 2018/19, response differences among $\mathrm{N}$ treatments became more distinct, with YAN increasing with increasing $\mathrm{N}$ rate (Table 12). A similar positive increase was observed in Chardonnay in both 2016/17 and 2017/18, but not in 2018/19 (Table 13). Overall, YAN concentrations were very low in 2017/18 across both cultivars (Tables 12 and 13).

Juice TSS, $p H$, TA, and phenolics. There were no interactions between irrigation and $\mathrm{N}$ treatments for juice TSS, $\mathrm{pH}$, or TA in either cultivar over the three seasons. $\mathrm{N}$ treatments alone did not affect juice TSS, pH, or TA over the trial period (Tables 12 and 13). As the TA analysis was not performed on fresh juice samples, the TA values reported are not considered entirely accurate, as freezing and defrosting samples may result in tartrate precipitation. However, relative differences between treatments are still considered valid as the samples were handled and treated in the same manner.

The impact of irrigation rate on juice TSS, $\mathrm{pH}$, and TA was generally inconsistent and minor across seasons (Tables 12 and 13). In Chardonnay, juice TA was higher under double irrigation in 2016/17 only (Table 12). In Pinot noir, juice TSS was higher in response to double irrigation in 2017/18 only (Table 13). In Chardonnay in 2016/17, juice phenolics were higher in the control $\mathrm{N}$ treatment, but only under standard irrigation (Table 7). In Pinot noir in 2018/19, grape phenolics and tannins decreased under double irrigation and in the double $\mathrm{N}$ treatment (Table 13).

Wine $\mathrm{pH}$ and TA. Wine $\mathrm{pH}$ and TA were inconsistently affected by $\mathrm{N}$ and irrigation treatments across cultivars and seasons (Tables 14 and 15). In general, there was no interaction between treatments, except for Chardonnay in 2018/19, where grapevines receiving double irrigation produced wine with higher $\mathrm{pH}$ levels than standard irrigation, but only under the control $\mathrm{N}$ treatment (Table 7). In Chardonnay in $2017 / 18$, wine TA increased in the double $N$ treatment in comparison to the control $\mathrm{N}$ treatment, yet remained unaffected in the other trial seasons (Table 14). In Pinot noir in 2018/19, wine $\mathrm{pH}$ was higher with the standard $\mathrm{N}$ treatment than with the control $\mathrm{N}$ treatment, despite a lack of effect on juice $\mathrm{pH}$ in the same year (Table 15). The imposed irrigation treatments had minimal influence on wine TA or $\mathrm{pH}$. Wine TA increased with double irrigation in Chardonnay in 2016/17 and 2017/18 (Table 14), while wine $\mathrm{pH}$ and TA were unaffected by irrigation rate in Pinot noir (Table 15).

Wine phenolics. In the first season of the Chardonnay trial (2017/18), double irrigation led to a reduction in total phenolics in wine under the control $\mathrm{N}$ treatment, but irrigation had no effect under the other $\mathrm{N}$ treatments (Table 7). In 2018/19, this same pattern was observed, and lower wine phenolics were observed with double irrigation, but only in the standard N treatment. In Pinot noir in 2018/19, a decrease in wine phenolics and tannins was observed with double irrigation under the standard $\mathrm{N}$ treatment (Table 9). Irrigation had no impact on wine phenolics at the other $\mathrm{N}$ rates, but conversely, double irrigation increased wine total tannins under the double $\mathrm{N}$ treatment.

The impact of $\mathrm{N}$ treatments on wine phenolics was limited. In Chardonnay in 2016/17, the wine phenolics response to $\mathrm{N}$ followed an inverted bell curve-shape, with standard $\mathrm{N}$ treatments producing wine with lower phenolics than double N (Table 14).

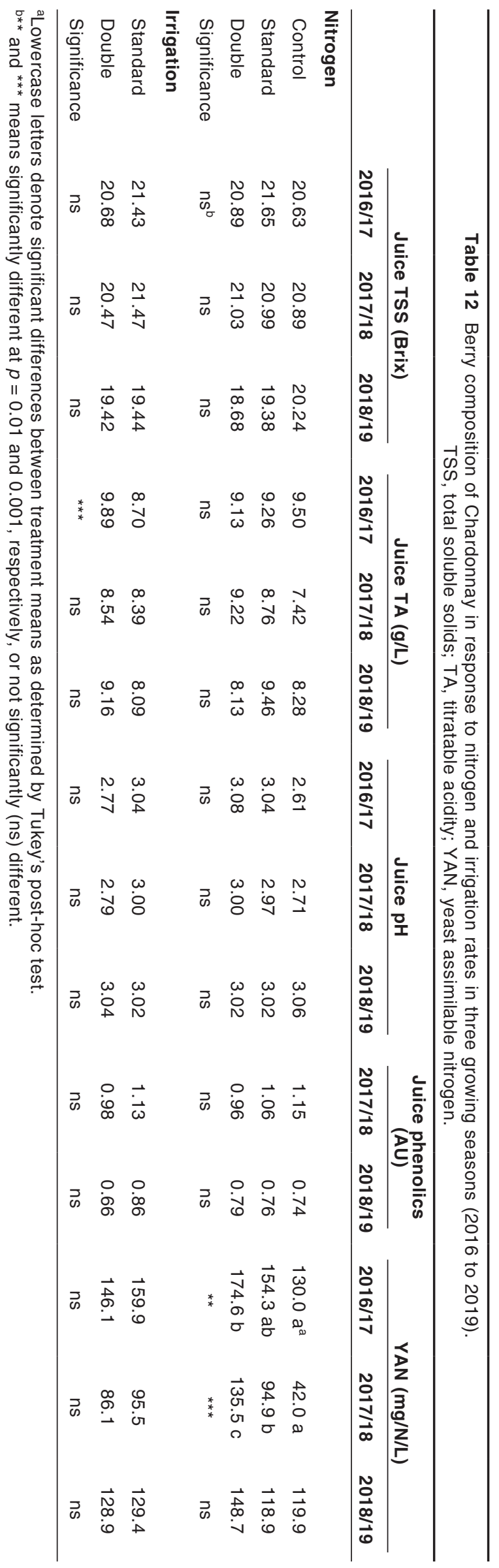




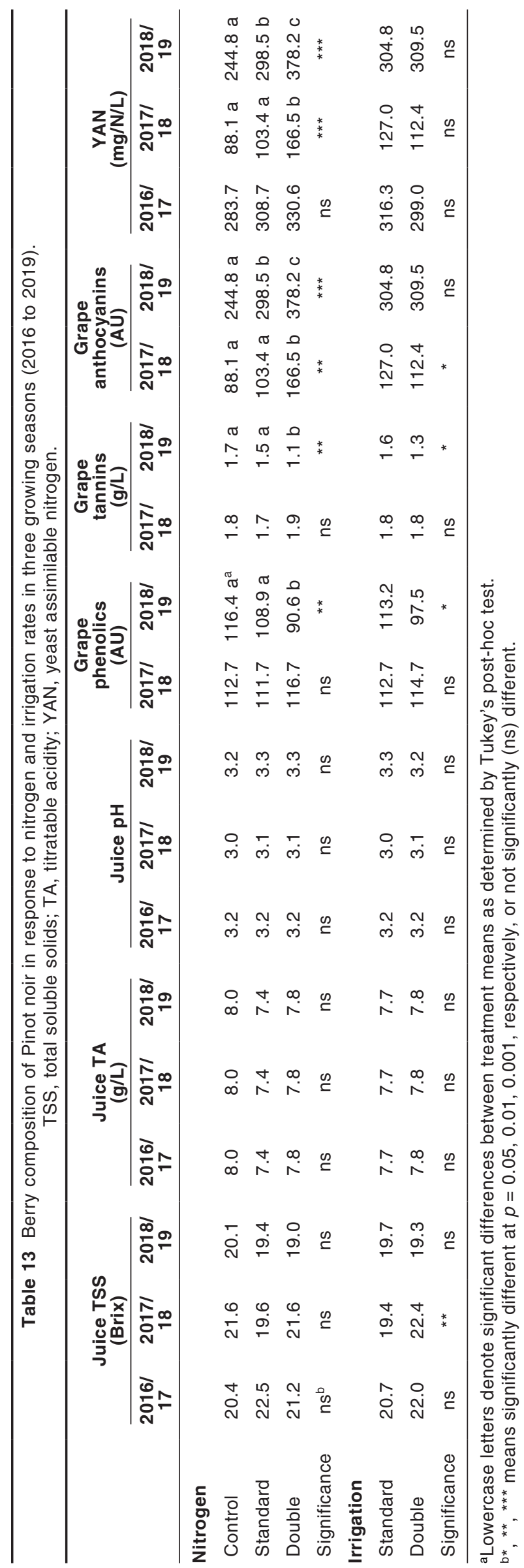

However, no differences were observed among treatments in the following trial seasons. In Pinot noir in 2018/19, total wine pigment decreased under the double $\mathrm{N}$ treatment (Table 15). Non-bleachable pigment was likewise lower under the double $\mathrm{N}$ treatment, but only in comparison to standard $\mathrm{N}$ rates (Table 15).

Irrigation effects on wine phenolics were inconsistent among seasons. In 2016/17 in Chardonnay, wine phenolics were lower under double irrigation (Table 14). In Pinot noir, in 2017/18, wine phenolics and tannins were higher with double irrigation (Table 15).

\section{Discussion}

This study on two cool-climate grapevine cultivars showed that the most discernable influence of $\mathrm{N}$ treatments was on YAN concentration, while there were marginal and inconsistent treatment impacts on vine canopy, vigor, yield, and grape and wine composition. These findings align closely with a review of the impact of $\mathrm{N}$ nutrition on grapes, fermentation, and wine, demonstrating that the only consistent effect of increased $\mathrm{N}$ application on grape berry quality was an increase in berry nitrogenous compounds, often leading to an increase in juice and must YAN (Bell and Henschke 2005). The vines used in our study were relatively young at trial commencement (three-years-old) and as a result, vine reserves were likely low and the root systems small, resulting in higher $\mathrm{N}$ requirements relative to mature vines (Verdenal et al. 2021). Despite this, the additional $\mathrm{N}$ supplied by the double $\mathrm{N}$ treatment had minimal impact on the measured variables apart from YAN, suggesting that under lower $\mathrm{N}$ rates, YAN is not prioritized by the vine. In the final year of the trial (2018/19), Chardonnay vine vigor and yield were lower in the control $(0 \mathrm{~N})$ treatment, suggesting that over time, low $\mathrm{N}$ rates in young vines reduce productivity as $\mathrm{N}$ reserves are depleted. Due to the limited amount of research on grapevine $\mathrm{N}$ fertilization rate, the following discussion is not limited to cool-climate wine regions.

YAN. In two of the three trial years, Pinot noir homogenate extract and Chardonnay juice YAN concentrations showed an increase with the additional $\mathrm{N}$ applied compared to the $0 \mathrm{~N}$ control. A large proportion of $\mathrm{N}$ is located in grape skins and seeds, and for skin-contact winemaking cultivars such as Pinot noir, it is likely that this contact during pressing, maceration, and fermentation provides yeast with additional access to $\mathrm{N}$ beyond juice YAN (Stines et al. 2000, Bell and Henschke 2005, Ribéreau-Gayon et al. 2006). A study on the amino acid contribution of grape seeds, skins, and pulp to Riesling and Cabernet Sauvignon found 19 to $29 \%$ of yeast-assimilable amino acids present in the skins and 10 to $15 \%$ in the seeds (Stines et al. 2000), while another study found $50 \%$ of final yeast-assimilable amino acids present in Cabernet Sauvignon skins (Bouard et al. 2000). Although the Pinot noir YAN measurements in this study are not directly comparable to others due to the homogenization procedure used, the differences observed between $\mathrm{N}$ treatments are legitimate, as the samples were treated homogenously. We expected that we would observe higher YANs than reported in other studies, because our homogenization procedure included the skin and seeds. Regardless of the YAN measurement procedure, no minimum YAN concentration for high-solid red wine ferments has been published (Bell and Henschke 2005). Using the levels recommended for clarified juice samples, the Pinot noir YAN concentrations in this study could be 
considered deficient or low across all $\mathrm{N}$ treatments relative to the conventionally used $140 \mathrm{mg} / \mathrm{N} / \mathrm{L}$ YAN threshold, under the assumption that juice extractions fall 29 to $50 \%$ lower than actual YAN concentrations due to the contribution of $\mathrm{N}$ in grape skins (Bouard et al. 2000, Stines et al. 2000). Due to the nature of this study, DAP was added to all ferments to ensure fermentation completion and therefore, the direct impact of $\mathrm{N}$ rates on fermentation kinetics and actual YAN thresholds could not be evaluated. This is a realistic scenario, as DAP addition in low YAN $(<140 \mathrm{mg} / \mathrm{N} / \mathrm{L})$ grape juices and musts is a common winery intervention, particularly in cool climate wine regions. Nonetheless, the relative differences in wine composition between $\mathrm{N}$ treatments are comparable. YAN concentrations in Chardonnay also tended to be deficient $(<140 \mathrm{mg} / \mathrm{N} / \mathrm{L})$ or at the lower acceptable range of suggested concentrations. Yet in this case, increasing $\mathrm{N}$ from the standard $\mathrm{N}$ rate to the double $\mathrm{N}$ rate did increase deficient $(<140 \mathrm{mg} / \mathrm{N} / \mathrm{L})$ YAN concentrations to close to acceptable YAN levels ( $>140 \mathrm{mg} / \mathrm{N} / \mathrm{L}$ ) in 2017/18. Nevertheless, it should be noted that the increase in YAN was not proportional to the

Table 14 Wine composition of Chardonnay in response to nitrogen and irrigation rates in three growing seasons (2016 to 2019).TA, titratable acidity.

\begin{tabular}{|c|c|c|c|c|c|c|}
\hline & \multicolumn{3}{|c|}{$\begin{array}{c}\text { Wine TA } \\
(g / L)\end{array}$} & \multicolumn{2}{|c|}{ Wine $\mathrm{pH}$} & \multirow{2}{*}{$\begin{array}{c}\begin{array}{c}\text { Wine } \\
\text { phenolics } \\
\text { (AU) }\end{array} \\
2016 / 17\end{array}$} \\
\hline & 2016/17 & 2017/18 & 2018/19 & $2016 / 17$ & $2017 / 18$ & \\
\hline \multicolumn{7}{|l|}{ Nitrogen } \\
\hline Control & 9.12 & $9.67 \mathrm{a}^{\mathrm{a}}$ & 9.14 & 3.12 & 3.00 & $1.20 \mathrm{ab}$ \\
\hline Standard & 8.91 & $9.95 a b$ & 8.93 & 3.30 & 3.00 & $1.12 \mathrm{a}$ \\
\hline Double & 8.78 & $10.61 \mathrm{~b}$ & 10.48 & 3.31 & 3.05 & $1.25 \mathrm{~b}$ \\
\hline Significance & $\mathrm{ns}^{\mathrm{b}}$ & * & ns & ns & ns & * \\
\hline \multicolumn{7}{|l|}{ Irrigation } \\
\hline Standard & 8.52 & 9.79 & 9.04 & 3.24 & 3.02 & 1.23 \\
\hline Double & 9.35 & 10.37 & 10.00 & 3.24 & 3.01 & 1.15 \\
\hline Significance & $* * *$ & * & ns & ns & ns & * \\
\hline
\end{tabular}

aLowercase letters denote significant differences between treatment means as determined by Tukey's post-hoc test.

${ }^{b *}$ and ${ }^{* * *}$ means significantly different at $p=0.05$ and 0.001 , respectively, or not significantly (ns) different. amount of $\mathrm{N}$ applied in the double $\mathrm{N}$ treatment, suggesting that $\mathrm{N}$ use efficiency may be reduced at greater $\mathrm{N}$ application rates. There was a trend for increased $\mathrm{N}$ in the double $\mathrm{N}$ rate treatment canopies in each of the three seasons (Table 6), suggesting that the additional $\mathrm{N}$ may have increased $\mathrm{N}$ storage in the perennial organs. Yet as the $\mathrm{N}$ was applied as a mobile nitrate form, there is the potential that surplus $\mathrm{N}$ was lost to the environment as either $\mathrm{N}_{2} \mathrm{O}$ gas (Swarts et al. 2016) or leached below the root zone (Nováková and Nágel 2009). In another Tasmanian texture contrast soil, the infiltration of fertigation nitrate in an apple orchard was largely restricted to A1 soil horizons under standard fertigation and irrigation practices, despite infiltrating water penetrating further to the A2 and upper B2 horizons (Hardie et al. 2018). This demonstrates that nitrate losses through leaching can be minimized with good fertigation management and suggests that nitrate leaching in this study should have been minimal, given the careful monitoring of crop evapotranspiration and soil moisture undertaken by the grower.

The amount of $\mathrm{N}$ required to achieve suggested YAN concentrations $(140 \mathrm{mg} / \mathrm{N} / \mathrm{L})$ varied between growing seasons. YAN concentrations across both Pinot noir and Chardonnay blocks were substantially lower in the 2017/18 season, likely in response to the high yields experienced in that season. This suggests that in high-crop load years, $\mathrm{N}$ application must be monitored closely and increased to meet YAN requirements.

The relatively high rainfall during the bloom to veraison $(113.6 \mathrm{~mm})$ and veraison to harvest $(117.4 \mathrm{~mm})$ growing periods (Supplemental Table 1), when N fertilization was applied, may also have contributed to nitrate leaching in the soil and decreased $\mathrm{N}$ uptake, reducing $\mathrm{N}$ translocation to grape bunches and therefore YAN. On the other hand, increasing irrigation did not affect YAN concentrations across both cultivars over the trial period. Because most of the research undertaken on the impact of irrigation rate on YAN is based on decreasing standard irrigation rates (Wade et al. 2004, Hannam et al. 2013, Holzapfel et al. 2015), the impact of additional irrigation on YAN is largely unknown. Yet, in reduced irrigation studies, YAN improvements were mainly

Table 15 Wine composition of Pinot noir in response to nitrogen and irrigation rates in three growing seasons (2016 to 2019). TA, titratable acidity.

\begin{tabular}{|c|c|c|c|c|c|c|c|c|c|c|c|c|c|c|}
\hline & \multicolumn{3}{|c|}{ Wine TA $(\mathrm{g} / \mathrm{L})$} & \multicolumn{3}{|c|}{ Wine $\mathrm{pH}$} & \multirow{2}{*}{$\begin{array}{c}\text { Wine } \\
\text { phenolics } \\
\text { (AU) } \\
2017 / 18\end{array}$} & \multirow{2}{*}{$\begin{array}{c}\begin{array}{c}\text { Wine } \\
\operatorname{tannins} \\
(\mathrm{g} / \mathrm{L})\end{array} \\
2017 / 18\end{array}$} & \multicolumn{2}{|c|}{$\begin{array}{c}\text { Wine } \\
\text { anthocyanins } \\
\text { (AU) }\end{array}$} & \multicolumn{2}{|c|}{$\begin{array}{l}\text { Wine total } \\
\text { pigment } \\
\text { (AU) }\end{array}$} & \multicolumn{2}{|c|}{$\begin{array}{c}\text { Non-bleachable } \\
\text { pigment } \\
\text { (AU) }\end{array}$} \\
\hline & $2016 / 17$ & $2017 / 18$ & $2018 / 19$ & $2016 / 17$ & $2017 / 18$ & $2018 / 19$ & & & $2017 / 18$ & $2018 / 19$ & $2017 / 18$ & $2018 / 19$ & $2017 / 18$ & $2018 / 19$ \\
\hline \multicolumn{15}{|l|}{ Nitrogen } \\
\hline Control & 7.4 & 7.7 & 6.7 & 3.6 & 3.4 & $3.8 \mathrm{a}^{\mathrm{a}}$ & 29.7 & 0.7 & 32.5 & 35.8 & 4.4 & $4.7 \mathrm{a}$ & 1.6 & $1.9 a b$ \\
\hline Standard & 7.2 & 8.1 & 5.9 & 3.7 & 3.0 & $3.9 \mathrm{~b}$ & 28.8 & 0.4 & 29.6 & 25.1 & 4.2 & $5.3 \mathrm{a}$ & 1.6 & $2.6 \mathrm{~b}$ \\
\hline Double & 7.2 & 9.0 & 6.2 & 3.7 & 3.3 & $3.8 a b$ & 30.9 & 0.6 & 33.1 & 22.0 & 4.2 & $3.1 \mathrm{~b}$ & 1.5 & $1.3 \mathrm{a}$ \\
\hline Significance & $n s^{b}$ & ns & ns & ns & ns & * & $\mathrm{ns}$ & ns & $\mathrm{ns}$ & ns & ns & ** & ns & $\star *$ \\
\hline \multicolumn{15}{|l|}{ Irrigation } \\
\hline Standard & 7.3 & 9.1 & 6.3 & 3.7 & 3.0 & 3.8 & 25.1 & 0.4 & 21.7 & 26.0 & 3.4 & 4.5 & 1.4 & 2.1 \\
\hline Double & 7.3 & 7.3 & 6.2 & 3.6 & 3.4 & 3.8 & 33.7 & 0.7 & 39.9 & 29.5 & 4.9 & 4.2 & 1.7 & 1.8 \\
\hline Significance & ns & ns & ns & ns & ns & ns & * & * & ns & ns & ns & ns & ns & ns \\
\hline
\end{tabular}

aLowercase letters denote significant differences between treatment means as determined by Tukey's post-hoc test.

${ }^{b *}$ and ${ }^{* *}$ means significantly different at $p=0.05$ and 0.01 , respectively, or not significantly (ns) different. 
driven by reductions in yield and/or berry size (Hannam et al. 2013, Holzapfel et al. 2015). Based on this principle, it is not surprising that YAN was unaffected by the double irrigation rate in this study, given the lack of impact of irrigation rate on yield and the inconsistent influence of irrigation rate and treatment interactions $(\mathrm{N} \times$ irrigation $)$ on berry size. There were no interactive effects of $\mathrm{N}$ and irrigation on YAN, indicating that the double irrigation rate did not influence the amount of $\mathrm{N}$ translocated into grape clusters.

Vine canopy and vigor. Vine canopy characteristics, as measured by the point quadrat method (PQ), were not influenced by $\mathrm{N}$ and irrigation treatment interactions or by $\mathrm{N}$ treatments alone. This suggests that the double $\mathrm{N}$ rate, which averaged $\sim 36 \mathrm{~kg} / \mathrm{N} /$ ha per year across both blocks, may have been too low to affect vegetative growth or that the timing of $\mathrm{N}$ application, which mostly occurred just prior to veraison (Tables 2 and 3), may have limited the influence of $\mathrm{N}$ supply on vine vegetative response. Other studies on grape cultivars suited to cooler climates have applied upwards of $60 \mathrm{~kg} / \mathrm{N} / \mathrm{h}$ a for a moderate to high $\mathrm{N}$ rate (Keller et al. 1999, Linsenmeier et al. 2008); the current study was designed as a grower-managed manipulation of current vineyard practices, where the double $\mathrm{N}$ rate was set as a comparison to their standard practice. Despite the modest $\mathrm{N}$ rates used in this study, vine canopy response to $\mathrm{N}$ application in cool climate wine regions appears to be small and inconsistent, even at greater $\mathrm{N}$ rates.

No changes to vine canopy variables measured for the control $(0 \mathrm{~N})$ treatment over the three-year period suggests that sufficient vine $\mathrm{N}$ reserves were available and the supply of $\mathrm{N}$ from the soil was enough to sustain adequate vegetative growth. Decreased LLN was measured at veraison in unfertilized Cabernet Sauvignon vine canopies $(0 \mathrm{~kg} / \mathrm{N} / \mathrm{ha})$ compared to fertilized canopies $(92.6,185.2,370.4$, and $740.8 \mathrm{~kg} / \mathrm{N} / \mathrm{ha})$ in each season of a three-year trial (Bell and Robson 1999). However, much greater $\mathrm{N}$ treatment rates were applied, and the trial was conducted on a site characterized by low soil fertility, suggesting that initial $\mathrm{N}$ reserves may have been low. Löhnertz (1991) suggested that fertilizer studies that only span a few years are not representative of how $\mathrm{N}$ rate impacts vegetative growth, due to the nature of how $\mathrm{N}$ is stored in wood. Yet, despite the lack of impact of $\mathrm{N}$ treatments on vine canopies, pruning weights were lower in the Chardonnay control treatment by the conclusion of the trial in 2018/19, indicating that $\mathrm{N}$ was becoming deficient. In Pinot noir, an increase in pruning weights in the double $\mathrm{N}$ treatment in the final year of the trial was also observed, again demonstrating an impact of $\mathrm{N}$ rate on vine vigor, although no differences in canopy architecture were observed.

Irrigation rate only impacted vine canopy and vine vigor in the 2017/18 growing season, with denser vine canopies observed for Chardonnay under double irrigation and the opposite effect observed for Pinot noir. This response is likely a result of soil type differences between the two blocks. The Chardonnay grapevines were grown in a shallow black clay loam soil, with a heavy clay subsoil characterized by a high water-holding capacity, while the Pinot noir grapevines were grown in a lateritic sandy loam. It is possible that increased rainfall in 2016/17 helped recharge soil water reserves in the Chardonnay block, meaning more water was available in the following season. This increase in water availability in 2017/18, particularly earlier in the season, coupled with double irrigation, may have stimulated vegetative growth, measured as increased leaf contacts and LLN, in Chardonnay. Alternatively, the decrease observed in leaf contacts and LLN in Pinot noir in 2017/18 may reflect nutrient leaching as a result of additional water supply in the high-draining sandy loam soil, resulting in less dense canopies. Indeed, leaf $\mathrm{N}$ concentrations measured at harvest in the 2017/18 growing season showed that double irrigation decreased leaf $\mathrm{N}$ below that of standard irrigation. This same pattern was also observed with Chardonnay; however, the additional water held by the soil may have been sufficient to stimulate vegetative growth regardless of nutrient availability.

Despite the inconsistent irrigation treatment effect on canopies, double irrigation increased vine vigor in both cultivars in 2017/18, as shown by an increase in pruning weights. There was strong correlation between shoot growth and soil moisture in Sultanina grapevines, with strong positive association between shoot length and irrigation level $(0.50,0.75,1.00$ of evapotranspiration) over a three-year period (Paranychianakis et al. 2004). As the dormancy period in this study was uncharacteristically dry in $2017 / 18$, more irrigation was applied earlier in the season (budbreak to bloom) than in other trial years, so the earlier application of water may be responsible for the differences observed in pruning weights, as this may have stimulated early shoot growth in this season.

Yield and yield variables. $\mathrm{N}$ fertilization and irrigation in the vineyard is intended to increase yields by increasing the overall capacity of the vine. Interactions between $\mathrm{N}$ and irrigation treatments existed mainly for cluster weight and berry size variables, although these were inconsistent across trial seasons and cultivars. In 2016/17 only, applying double irrigation to vines receiving the double $\mathrm{N}$ treatment increased cluster weight in both Chardonnay and Pinot noir. In Chardonnay, the cluster weight increase was driven by an increase in berries per cluster, which is determined by conditions influencing inflorescence initiation and differentiation during the prior season and by fruit set in the existing season (Guilpart et al. 2014, Li-Mallet et al. 2016). Inadequate N around fruit set can lead to flower abscission (Keller et al. 1998). In this study, a low annual growing season rainfall of $256 \mathrm{~mm}$ during the prior season $(2015 / 16)$ may have led to some degree of vine water stress, which may have influenced the response of vines to the double $\mathrm{N}$ treatment in 2016/17. The additional $\mathrm{N}$ may have improved fruit set and thereby increased berries per cluster, but only when irrigation was sufficient to allow effective $\mathrm{N}$ uptake. In Pinot noir, the observed increase in cluster weight was driven by more larger berries, as represented by the berry size ratio. In agreement with a previous study (Triolo et al. 2018), our results suggest that berry weight (size) increased when $\mathrm{N}$ and water supply were not limited, most likely due to their influence on cell division and/or cell expansion. 
The main effects of $\mathrm{N}$ and irrigation treatments on yield variables were minimal and inconsistent. In Chardonnay, yield increases with $\mathrm{N}$ fertilizer application in 2018/19 reflected more, heavier clusters and larger berries, yet there was no influence of $\mathrm{N}$ treatments for Pinot noir. Several studies have found that cluster number accounts for $\approx 60 \%$ of seasonal yield variation (Dunn and Martin 2007, Guilpart et al. 2014, Li-Mallet et al. 2016), and although it is primarily determined by pruning approach, secondary influences on bud fruitfulness and differentiation through climate, irrigation, and mineral nutrition can play a significant role. While the influence of $\mathrm{N}$ supply on cluster number remains poorly understood (Li-Mallet et al. 2016), N stress has been associated with a decrease in potential cluster number in response to a decrease in bud fruitfulness (Guilpart et al. 2014). Indeed, sufficient $N$ is necessary for optimal inflorescence primordium formation and flower differentiation (Vasconcelos et al. 2009). Fruit set was reduced as a result of inflorescence necrosis due to low $\mathrm{N}$ fertilization at bloom (Keller et al. 1998), while there was a $16 \%$ reduction in yield for zero $\mathrm{N}$ treatments in Riesling when averaging yields over a 15-year trial (Linsenmeier et al. 2008). In alignment with these findings, it is therefore possible that in Chardonnay, the lack of $\mathrm{N}$ provided in the $0 \mathrm{~N}$ treatment disrupted yield formation, suggesting that the reproductive capabilities of the vine were impacted more by reduced $\mathrm{N}$ supply than vegetative production, as suggested elsewhere (Keller et al. 2001).

Grape and wine composition. Reduced berry size, such as through low $\mathrm{N}$ supply and water deficit, has been linked to increased juice and grape phenolics (Bell and Henschke 2005). In 2016/17, grape juice phenolics were more abundant under standard irrigation in the Chardonnay $0 \mathrm{~N}$ treatment, which may be a response to the lower cluster weights and reduced berry size in this treatment. In agreement with another study (Triolo et al. 2018), our findings suggest that water availability is a greater driver of berry size than $\mathrm{N}$, as low $\mathrm{N}$ supply does not appear to limit berry size or increase juice phenolics when water supply is increased. In Chardonnay, wine phenolic content also tended to be lower with double irrigation with different $\mathrm{N}$ rates and between seasons, which could again be attributed to changes in berry size, suggesting that the standard irrigation rates applied by the grower are generally adequate for juice and wine quality.

Juice composition (TSS, TA, pH) was unaffected by $\mathrm{N}$ treatments in both cultivars, whereas wine composition (TA, $\mathrm{pH}$ ) was influenced inconsistently. A similar result on juice TSS, TA, and $\mathrm{pH}$ was found in an 11-year study on Chenin blanc vines, finding no influence of $\mathrm{N}$ rate $(16,56,96 \mathrm{~kg} / \mathrm{N} /$ ha/year) (Conradie and Saayman 1989). The impact of $\mathrm{N}$ fertilization on juice TSS, TA, and $\mathrm{pH}$ was generally inconclusive, due to the high variability both within and between studies, where differences were more influenced by external factors, including climate, environment, cultural practices, and genetics (Bell and Henschke 2005).

Microvinification allows adequate replication and control of the winemaking process, which is often difficult to achieve on an industrial scale due to production logistics, risks, and cost (Dambergs and Sparrow 2011). Pinot noir phenolic composition has been found to be independent of fermentation vessel and must size for volumes ranging from 0.2 to $10 \mathrm{~kg}$, and similar phenolic profiles have been obtained using fruit from the same source in a $330 \mathrm{~kg}$ fermenter (Sparrow and Smart 2015). The Bodum French press method, as used for red winemaking in this trial, is a simple, submerged-cap method that can be non-invasively monitored and results in good extraction with reproducible fermentations (Dambergs and Sparrow 2011, Dambergs et al. 2012). There were few effects of $\mathrm{N}$ treatments on phenolics, tannin, and anthocyanin content of grape homogenates during the trial. Nevertheless, in the final season (2018/19), Pinot noir grape phenolics and tannins were lower in the double $\mathrm{N}$ rate treatment, likely as a result of compounding seasonal additions. As the double $\mathrm{N}$ rate did not influence canopy and yield in the same season, it is unlikely this treatment response is a consequence of differences in berry size and phenolic dilution. Rather, higher phenolic contents in the control and standard $\mathrm{N}$ treatments may have resulted from altered phenolic metabolism, in which the $\mathrm{N}$ rates imposed may have been low enough to impose a scenario of vine stress, leading to upregulation of secondary metabolite production (Keller 2005). The total phenolics in wine from the same vintage also correspond with this finding; the double $\mathrm{N}$ rate treatment had less phenolics than the other $\mathrm{N}$ treatments, although there was also a treatment interaction with irrigation. Thomidis et al. (2016) also found a reduction in Xinomavro berry phenolics with increasing $\mathrm{N}$ rates $(0,60,150 \mathrm{~kg} / \mathrm{N} / \mathrm{ha})$, yet the standard $\mathrm{N}$ rate applied in that study was much greater than the double $\mathrm{N}$ treatment in this trial, highlighting that there may be thresholds in which $\mathrm{N}$ rate starts to impact secondary metabolism and berry phenolics.

The only main effect of increased irrigation on Chardonnay juice and wine quality was in TA, although seasonal variation was apparent. As in the current study, increased TA in response to additional irrigation is a common finding (Williams and Matthews 1990) and has been linked to an accelerated decrease in malic acid during berry ripening when water supply is limited (Esteban et al. 1999). Seasonal variations in juice TA in response to irrigation have been reported in cool-climate growing systems (Hannam et al. 2013, Balint and Reynolds 2014).

In Pinot noir, wine phenolics and tannins increased with double irrigation in 2017/18, which contrasts with other research that showed an increase in wine phenolics with water deficit (Roby et al. 2004). However, in this study, 2017/18 was a high-crop load year and double irrigation also increased vine canopy and vine vigor, suggesting that vines with double irrigation benefited from more source capacity, which may have enabled better phenolic development. Regarding N supply, additional water during high-yielding years is necessary for maintaining consistent wine composition. Although beyond the scope of this study, sensory analysis may have provided further insight into the influence of irrigation and $\mathrm{N}$ treatments on vine vigor, YAN, and wine composition, and should be a focus of further research. 


\section{Conclusions}

Excessive $\mathrm{N}$ rates and surplus water availability are generally associated with increased vine vigor and vegetative growth, increased yields, and negative impacts on grape and wine composition. As previously reported (Neilsen et al. 1989), the influence of $\mathrm{N}$ and irrigation treatments in this study were marginal and seasonally variable.

Given the minimal effect of the double $\mathrm{N}$ treatment on canopy, yield, and grape and wine composition, cool climate growers would benefit from applying more $\mathrm{N}$ in the vineyard around veraison to increase YAN without driving excessive vegetative vigor. For a more conservative approach, foliar urea application at veraison may improve YAN without substantial changes to vine $\mathrm{N}$ retention, vine growth, and no-tolittle change to juice quality (Hannam et al. 2014, Mataffo et al. 2020). The results also suggest that the standard irrigation rates used in this trial (430 to $600 \mathrm{~L} /$ vine) were adequate and there was no benefit from adding additional irrigation in a standard season. Additional irrigation may be beneficial in high-cropping years, when carbohydrate and nutrient demands are higher.

\section{Literature Cited}

AWRI. 2010. Nitrogen fertilisation. In Viti-notes: Grapevine Nutrition. Australian Wine Research Institute.

Balint G and Reynolds AG. 2014. Effect of different irrigation strategies on vine physiology, yield, grape composition and sensory profiles of Vitis vinifera L. Cabernet Sauvignon in a cool climate area. OENO One 48:269-292.

Bell AA, Ough CS and Kliewer WM. 1979. Effects on must and wine composition, rates of fermentation, and wine quality of nitrogen fertilization of Vitis vinifera var. Thompson Seedless grapevines. Am J Enol Vitic 30:124-129.

Bell SJ and Robson A. 1999. Effect of nitrogen fertilization on growth, canopy density, and yield of Vitis vinifera L. cv. Cabernet Sauvignon. Am J Enol Vitic 50:351-358.

Bell SJ and Henschke PA. 2005. Implications of nitrogen nutrition for grapes, fermentation and wine. Aust J Grape Wine Res 11:242-295.

Bouard J, Miele A and Carbonneau A. 2000. Composition en acides aminés libres des feuilles et des baies du cépage Cabernet Sauvignon. J Int Sci Vigne Vin 34:19-26.

Carew AL, Sparrow AM, Curtin CD, Close DC and Dambergs RG. 2014. Microwave maceration of Pinot noir grape must: Sanitation and extraction effects and wine phenolics outcomes. Food Bioprocess Technol 7:954-963.

Conradie WJ and Saayman D. 1989. Effects of long-term nitrogen, phosphorus, and potassium fertilization on Chenin blanc vines. II. Leaf analyses and grape composition. Am J Enol Vitic 40:91-98.

Dambergs R and Sparrow A. 2011. The "Bodum French Press": A simple, reliable small-lot red wine fermentation method. In Proceedings of the 14th Australian Wine Industry Technical Conference. p. 353, Poster no. 134.

Dambergs R, Sparrow A, Carew A, Scrimgeour N, Wilkes E, Godden P, Herderich M and Johnson D. 2012. Quality in cool climate-maceration techniques in Pinot Noir production. Wine Vitic J 27:18-26.

Dunn GM and Martin SR. 2007. A functional association in Vitis vinifera L. cv. Cabernet Sauvignon between the extent of primary branching and the number of flowers formed per inflorescence. Aust J Grape Wine Res 13:95-100.
Esteban MA, Villanueva MJ and Lissarrague JR. 1999. Effect of irrigation on changes in berry composition of Tempranillo during maturation. Sugars, organic acids, and mineral elements. Am J Enol Vitic 50:418-434.

Guilpart N, Metay A and Gary C. 2014. Grapevine bud fertility and number of berries per bunch are determined by water and nitrogen stress around flowering in the previous year. Eur J Agron 54:9-20.

Hannam K, Neilsen G, Forge T and Neilsen D. 2013. The concentration of yeast assimilable nitrogen in Merlot grape juice is increased by $\mathrm{N}$ fertilization and reduced irrigation. Can J Plant Sci 93:37-45.

Hannam KD, Neilsen GH, Neilsen D, Rabie WS, Midwood AJ and Millard P. 2014. Late-season foliar urea applications can increase berry yeast-assimilable nitrogen in winegrapes (Vitis vinifera L.). Am J Enol Vitic 65:89-95.

Hardie M, Ridges J, Swarts N and Close D. 2018. Drip irrigation wetting patterns and nitrate distribution: Comparison between electrical resistivity (ERI), dye tracer, and 2D soil-water modelling approaches. Irrig Sci 36:97-110.

Hilbert G, Soyer J, Molot C, Giraudon J, Milin M and Gaudillere J. 2003. Effects of nitrogen supply on must quality and anthocyanin accumulation in berries of cv. Merlot. Vitis 42:69-76.

Holzapfel BP, Watt J, Smith JP, Suklje K and Rogiers SY. 2015. Effects of timing of $\mathrm{N}$ application and water constraints on $\mathrm{N}$ accumulation and juice amino $\mathrm{N}$ concentration in 'Chardonnay' grapevines. Vitis 54:203-211.

Iland PG, Cynkar W, Francis IL, Williams PJ and Coombe BG. 1996. Optimisation of methods for the determination of total and red-free glycosyl glucose in black grape berries of Vitis vinifera. Aust J Grape Wine Res 2:171-178.

Iland P, Bruer N, Edwards G, Weeks S and Wilkes E. 2004. Chemical Analysis of Grapes and Wine: Techniques and Concepts. Patrick Iland Wine Promotions, Campbelltown, South Australia.

Jiranek V, Langridge P and Henschke P. 1995. Regulation of hydrogen sulfide liberation in wine-producing Saccharomyces cerevisiae strains by assimilable nitrogen. Appl Environ Microbiol 61:461-467.

Keller M. 2005. Deficit irrigation and vine mineral nutrition. Am J Enol Vitic 56:267-283.

Keller M, Arnink KJ and Hrazdina G. 1998. Interaction of nitrogen availability during bloom and light intensity during veraison. I. Effects on grapevine growth, fruit development, and ripening. Am J Enol Vitic 49:333-340.

Keller M, Pool RM and Henick-Kling T. 1999. Excessive nitrogen supply and shoot trimming can impair colour development in Pinot noir grapes and wine. Aust J Grape Wine Res 5:45-55.

Keller M, Kummer M and Vasconcelos MC. 2001. Reproductive growth of grapevines in response to nitrogen supply and rootstock. Aust J Grape Wine Res 7:12-18.

Kerslake F, Longo R and Dambergs R. 2018. Discrimination of juice press fractions for sparkling base wines by a UV-Vis spectral phenolic fingerprint and chemometrics. Beverages 4:45.

Kliewer WM. 1977. Influence of temperature, solar radiation and nitrogen on coloration and composition of Emperor grapes. Am J Enol Vitic 28:96-103.

Li-Mallet A, Rabot A and Geny L. 2016. Factors controlling inflorescence primordia formation of grapevine: their role in latent bud fruitfulness? A review. Botany 94:147-163.

Linsenmeier AW, Loos U and Löhnertz O. 2008. Must composition and nitrogen uptake in a long-term trial as affected by timing of nitrogen fertilization in a cool-climate Riesling vineyard. Am J Enol Vitic 59:255-264.

Löhnertz O. 1991. Soil nitrogen and the uptake of nitrogen in grapevines. In Proceedings of the International Symposium on Nitrogen in Grapes and Wine. Rantz JM et al. (eds.), pp. 1-11. ASEV, Davis, CA. 
Mataffo A, Scognamiglio P, Dente A, Strollo D, Colla G, Rouphael $\mathrm{Y}$ and Basile B. 2020. Foliar application of an amino acid-enriched urea fertilizer on 'Greco' grapevines at full veraison increases berry yeast-assimilable nitrogen content. Plants 9:619.

Mercurio MD, Dambergs RG, Herderich MJ and Smith PA. 2007. High throughput analysis of red wine and grape phenolics-adaptation and validation of methyl cellulose precipitable tannin assay and modified Somers color assay to a rapid 96 well plate format. J Agric Food Chem 55:4651-4657.

Neilsen GH, Stevenson DS and Fitzpatrick JJ. 1989. The effect of municipal wastewater irrigation and rate of $\mathrm{N}$ fertilization on petiole composition, yield and quality of Okanagan Riesling grapes. Can J Plant Sci 69:1285-1294.

Neilsen GH, Neilsen D, Bowen P, Bogdanoff C and Usher K. 2010. Effect of timing, rate, and form of $\mathrm{N}$ fertilization on nutrition, vigor, yield, and berry yeast-assimilable $\mathrm{N}$ of grape. Am J Enol Vitic 61:327-336.

Nováková K and Nágel D. 2009. The influence of irrigation on nitrates movement in soil and risk of subsoil contamination. Soil Water Res 4:S131-S136.

OIV. 2009. OIV descriptor list for grape varieties and vitis species. $2 \mathrm{~d}$ ed. Organisation Internationale de la Vigne et du Vin, Paris.

Paranychianakis NV, Aggelides S and Angelakis AN. 2004. Influence of rootstock, irrigation level and recycled water on growth and yield of Sultanina grapevines. Agric Water Manage 69:13-27.

Poni S, Rebucci B, Magnanini E and Intrieri C. 1996. Preliminary results on the use of a modified point quadrat method for estimating canopy structure of grapevine training systems. Vitis 35:23-28.

Ribéreau-Gayon P, Dubourdieu D, Donèche B and Lonvaud A. 2006. Handbook of Enology, Volume 1: The Microbiology of Wine and Vinifications. John Wiley \& Sons, Chichester, UK.

Roby G, Harbertson JF, Adams DA and Matthews MA. 2004. Berry size and vine water deficits as factors in winegrape composition: Anthocyanins and tannins. Aust J Grape Wine Res 10:100-107.

Sparrow AM and Smart RE. 2015. Fermentation volume studies for red wine experimentation. S Afr J Enol Vitic 36:343-346.

Spayd SE, Wample RL, Stevens RG, Evans RG and Kawakami AK. 1993. Nitrogen fertilization of White Riesling in Washington:
Effects on petiole nutrient concentration, yield, yield components, and vegetative growth. Am J Enol Vitic 44:378-386.

Spayd SE, Wample RL, Evans RG, Stevens RG, Seymour BJ and Nagel CW. 1994. Nitrogen fertilization of white Riesling grapes in Washington. Must and wine composition. Am J Enol Vitic 45:34-42.

Stines AP, Grubb J, Gockowiak H, Henschke PA, Høj PB and van Heeswijck R. 2000. Proline and arginine accumulation in developing berries of Vitis vinifera L. in Australian vineyards: Influence of vine cultivar, berry maturity and tissue type. Aust J Grape Wine Res 6:150-158.

Swarts N, Montagu K, Oliver G, Southam-Rogers L, Hardie M, Corkrey R, Rogers G and Close D. 2016. Benchmarking nitrous oxide emissions in deciduous tree cropping systems. Soil Res 54:500-511.

Thomidis T, Zioziou E, Koundouras S, Karagiannidis C, Navrozidis I and Nikolaou N. 2016. Effects of nitrogen and irrigation on the quality of grapes and the susceptibility to Botrytis bunch rot. Sci Hortic 212:60-68.

Triolo R, Roby JP, Plaia A, Hilbert G, Buscemi S, Di Lorenzo R and van Leeuwen C. 2018. Hierarchy of factors impacting grape berry mass: Separation of direct and indirect effects on major berry metabolites. Am J Enol Vitic 69:103-112.

Vasconcelos MC, Greven M, Winefield CS, Trought MCT and Raw V. 2009. The flowering process of Vitis vinifera: A review. Am J Enol Vitic 60:411-434.

Verdenal T, Dienes-Nagy A, Spangenberg JE, Zufferey V, Spring J-L, Viret O, Marin-Carbonne J and van Leeuwen C. 2021. Understanding and managing nitrogen nutrition in grapevine: A review. OENO One 55:1-43.

Wade J, Holzapfel B, Degaris K, Williams D and Keller M. 2004. Nitrogen and water management strategies for wine-grape quality. Acta Hortic 640:61-67.

Walker HV, Jones JE, Swarts ND, Rodemann T, Kerslake F and Dambergs RG. 2021. Predicting grapevine canopy nitrogen status using proximal sensors and near-infrared reflectance spectroscopy. J Plant Nutr Soil Sci 184:204-304.

Williams LE and Matthews MA. 1990. Grapevine. In Irrigation of Agricultural Crops (Agronomy monographs no. 30). Stewart BJ and Nielsen DR (eds), pp. 1019-1055. ASA-CSSA-SSSA, Madison, WI. 